ESRI

RESEARCH

SERIES

NUMBER 64

July 2017

\section{ILLEGAL EMPLOYMENT OF NON-EU NATIONALS IN IRELAND}

SAMANTHA ARNOLD, SUSAN WHELAN AND EMMA QUINN

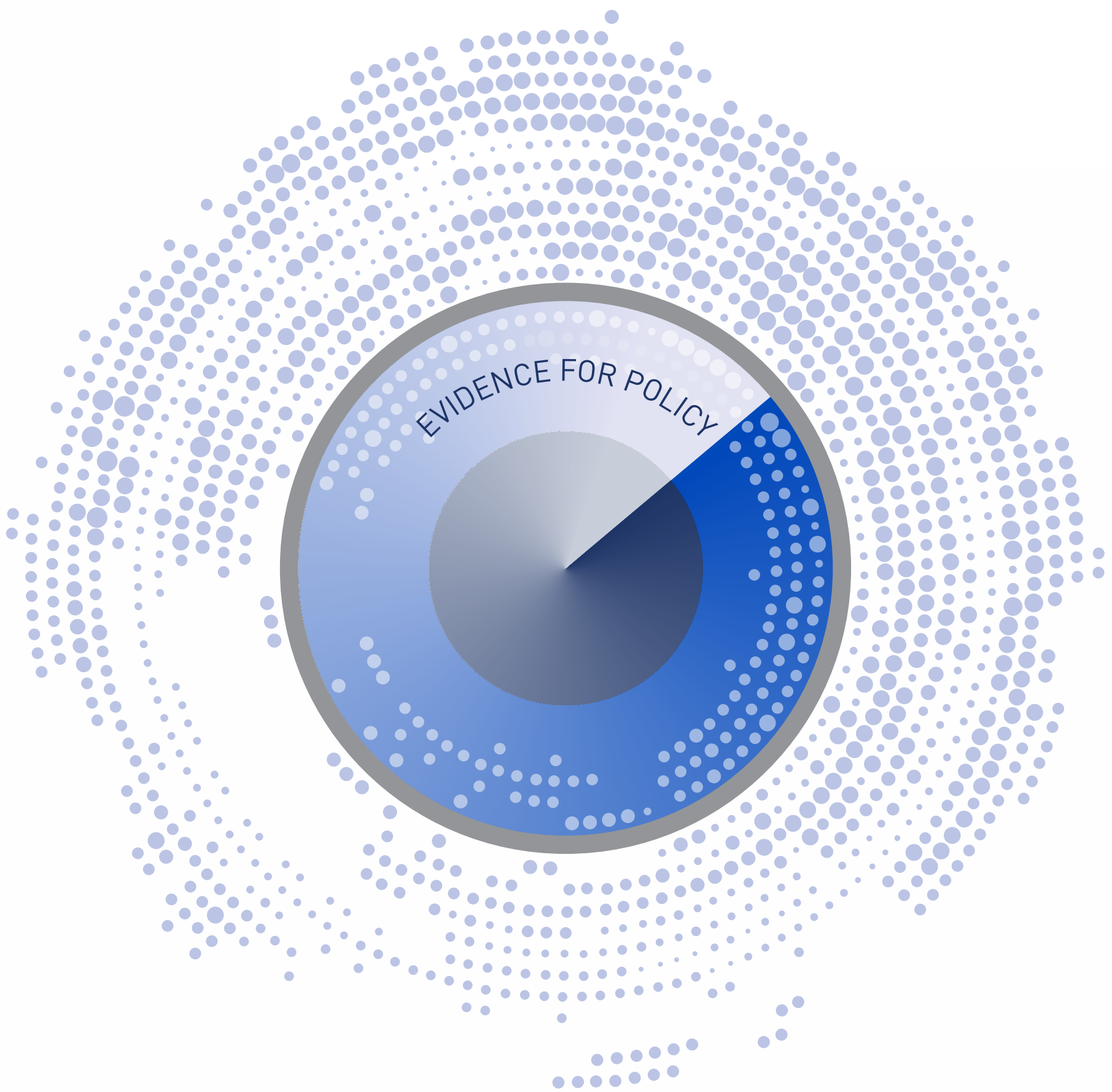




\section{ILLEGAL EMPLOYMENT OF NON-EU NATIONALS IN IRELAND}

Samantha Arnold

Susan Whelan

Emma Quinn

July 2017

\section{RESEARCH SERIES}

\section{NUMBER 64}

Available to download from www.esri.ie or www.emn.ie

(C) The Economic and Social Research Institute

Whitaker Square, Sir John Rogerson's Quay, Dublin 2

ISBN 978-0-7070-0436-5 


\section{THE EUROPEAN MIGRATION NETWORK}

The aim of the European Migration Network (EMN) is to provide up-to-date, objective, reliable and comparable information on migration and asylum at Member State and EU levels with a view to supporting policymaking and informing the general public.

The Irish National Contact Point of the European Migration Network, EMN Ireland, sits within the Economic and Social Research Institute (ESRI).

\section{ABOUT THE ESRI}

The mission of the Economic and Social Research Institute is to advance evidencebased policymaking that supports economic sustainability and social progress in Ireland. ESRI researchers apply the highest standards of academic excellence to challenges facing policymakers, focusing on 12 areas of critical importance to $21^{\text {st }}$ Century Ireland.

The Institute was founded in 1960 by a group of senior civil servants led by Dr T.K. Whitaker, who identified the need for independent and in-depth research analysis to provide a robust evidence base for policymaking in Ireland.

Since then, the Institute has remained committed to independent research and its work is free of any expressed ideology or political position. The Institute publishes all research reaching the appropriate academic standard, irrespective of its findings or who funds the research.

The quality of its research output is guaranteed by a rigorous peer review process. ESRI researchers are experts in their fields and are committed to producing work that meets the highest academic standards and practices.

The work of the Institute is disseminated widely in books, journal articles and reports. ESRI publications are available to download, free of charge, from its website. Additionally, ESRI staff communicate research findings at regular conferences and seminars.

The ESRI is a company limited by guarantee, answerable to its members and governed by a Council, comprising 14 members who represent a cross-section of ESRI members from academia, civil services, state agencies, businesses and civil society. The Institute receives an annual grant-in-aid from the Department of Public Expenditure and Reform to support the scientific and public interest elements of the Institute's activities; the grant accounted for an average of 30 per cent of the Institute's income over the lifetime of the last Research Strategy. The remaining funding comes from research programmes supported by government departments and agencies, public bodies and competitive research programmes.

Further information is available at www.esri.ie. 


\section{THE AUTHORS}

Samantha Arnold is a Post-Doctoral Research Fellow at the Irish National Contact Point of the European Migration Network (EMN), within the Economic and Social Research Institute (ESRI). Susan Whelan was Research Assistant at the Irish National Contact Point of the EMN. Emma Quinn is Head of the Irish National Contact Point of the EMN, within the ESRI.

\section{ACKNOWLEDGEMENTS}

In compiling this study valuable assistance was received from officials of: the Irish Naturalisation and Immigration Service and the Anti-Human Trafficking Unit within the Department of Justice and Equality; the Workplace Relations Commission; and the Department of Jobs, Enterprise and Innovation. Thanks are also due to representatives of the Migrant Rights Centre Ireland.

We also acknowledge the useful comments and suggestions received from our colleagues and the referees.

Finally, thanks are also due to our colleagues Anne Sheridan, Elaine Byrne and Sarah Burns at the ESRI. We are grateful to everyone who shared their expertise with us for the purpose of writing this study.

\section{ABOUT THIS REPORT}

This European Migration Network study discusses the illegal employment of nonEU nationals who have a right to reside in Ireland but not a right to work, and nonEU nationals working in Ireland without a right to reside. The study focusses on policy, law and practice in Ireland in relation to: prevention measures and incentives for compliance, direct policy initiatives, inspections, sanctions and outcomes for people found to be working illegally.

The report consists of information gathered by way of a common template, primarily for an overview, EU-level synthesis report Illegal employment of ThirdCountry Nationals in the European Union.

This report has been accepted for publication by the Institute, which does not itself take institutional policy positions. All ESRI Research Series reports are peer reviewed prior to publication. The authors are solely responsible for the content and the views expressed and do not represent the position of the Economic and Social Research Institute, the Irish Naturalisation and Immigration Service, the Department of Justice and Equality, or the European Commission, Directorate-General Migration and Home Affairs. 


\section{TABLE OF CONTENTS}

EXECUTIVE SUMMARY

VII

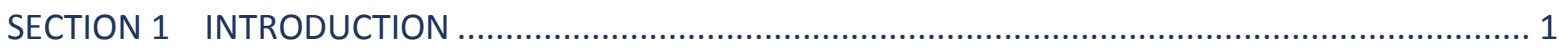

$1.1 \quad$ Objectives and background to the study..................................................... 1

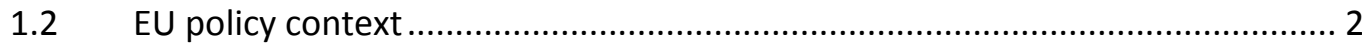

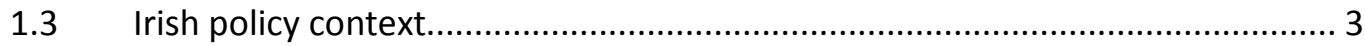

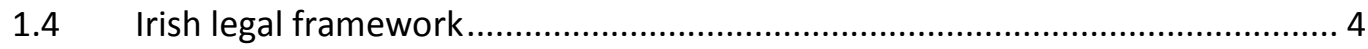

1.5 Overview of the main trends regarding illegal employment in Ireland .............. 6

1.5.1 Employment Permit breaches ................................................................ 8

1.5.2 Undocumented workers .................................................................... 10

1.5.3 Trafficking for the purposes of labour exploitation............................. 11

1.6 Overview of identified areas at high risk of illegal employment...................... 12

1.6.1 Spotlight on non-EU national students.............................................. 12

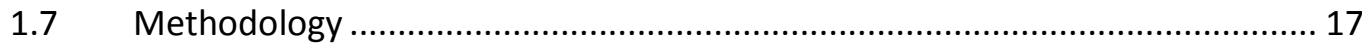

SECTION 2 PREVENTION MEASURES AND INCENTIVES AIMED AT COMBATTING ILLEGAL

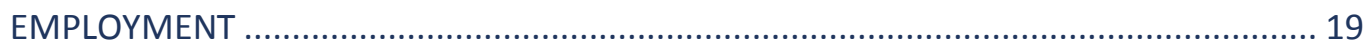

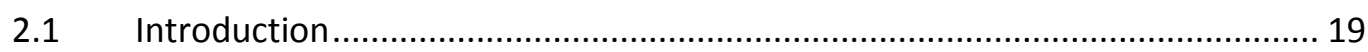

2.2 National authorities with responsibility for illegal employment...................... 19

2.2.1 Co-operation between national authorities ........................................ 20

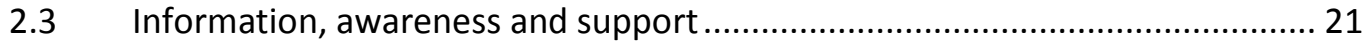

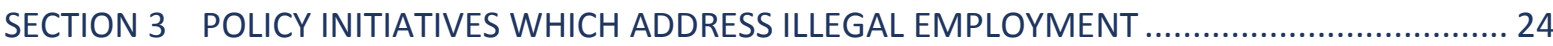

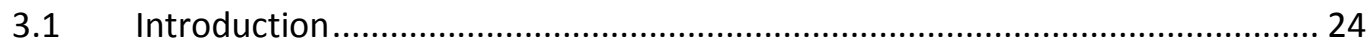

3.2 Reactivation employment permit scheme ..................................................... 24

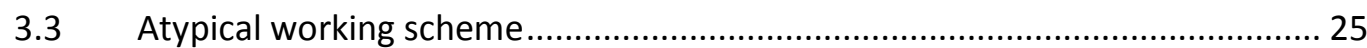

3.4 Student Probationary Extension................................................................... 26

3.4.1 Student graduates ….................................................................. 27

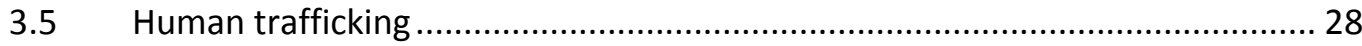

3.6 Improvements to the Employment Permits system ....................................... 29

3.7 Other options for regularisation............................................................... 30 
SECTION 4 IDENTIFICATION OF ILLEGAL EMPLOYMENT THROUGH INSPECTIONS .......................... 31

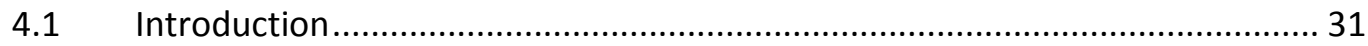

4.2 Overview of inspections framework................................................................ 31

4.3 Joint inspections and co-operation ................................................................. 32

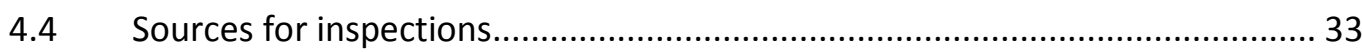

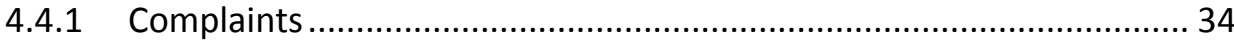

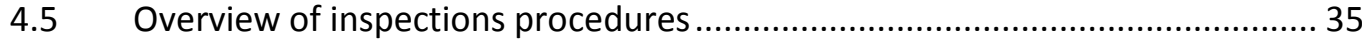

4.5.1 Information collection ................................................................... 35

4.5.2 Inspection procedure..................................................................... 36

4.5.3 Inspections in private dwellings ..................................................... 38

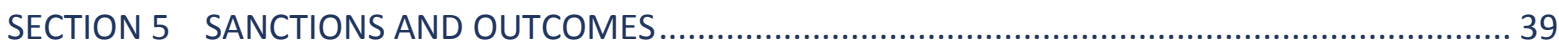

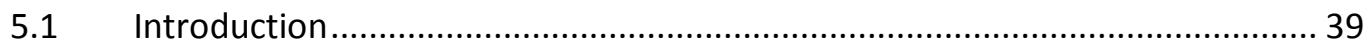

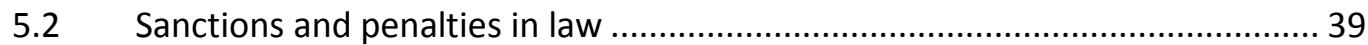

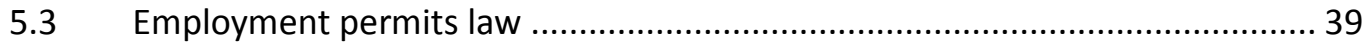

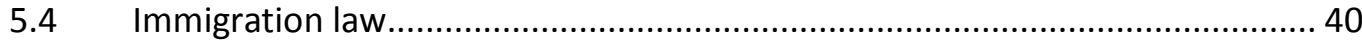

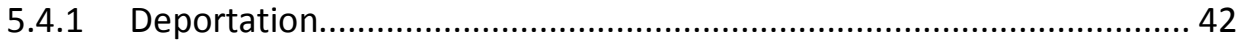

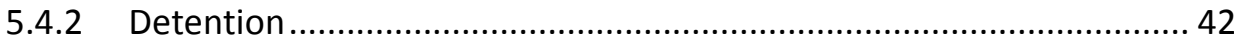

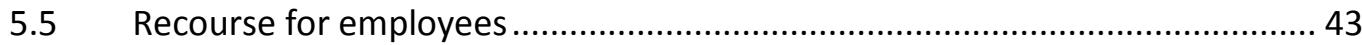

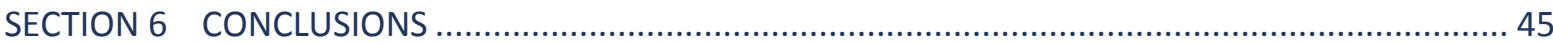

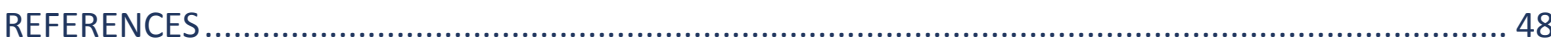




\section{LIST OF TABLES}

Table 1.1 Profile of persons employed in breach of Employment Permit Acts

(1 Oct 2011 - 15 Nov 2011)

Table 1.2 Suspected breaches of employment permits legislation 2011-2016 _...............................9

Table 1.3 Sanctions imposed by a Court under the Employment Permits Acts ................................10

\section{LIST OF FIGURES}

Figure 1.1 Non-EEA residence permits valid in Ireland (Non-EEA nationals aged 16 and over) 2011-2015 


\section{ABBREVIATIONS}

$\begin{array}{ll}\text { AHTU } & \text { Anti-Human Trafficking Unit } \\ \text { DFAT } & \text { Department of Foreign Affairs and Trade } \\ \text { DJE } & \text { Department of Justice and Equality } \\ \text { DJEI } & \text { Department of Jobs, Enterprise and Innovation } \\ \text { DSP } & \text { Department of Social Protection } \\ \text { EC } & \text { European Commission } \\ \text { EEA } & \text { European Economic Area } \\ \text { EMN } & \text { European Migration Network } \\ \text { ESRI } & \text { Economic and Social Research Institute } \\ \text { EROC } & \text { Emergency Reception and Orientation Centres } \\ \text { EU } & \text { European Union } \\ \text { GNIB } & \text { Garda National Immigration Bureau } \\ \text { GP } & \text { General Practitioner } \\ \text { ICRC } & \text { International Committee of the Red Cross } \\ \text { ILEP } & \text { Interim List of Eligible Programmes } \\ \text { ILO } & \text { International Labour Organization } \\ \text { INIS } & \text { Irish Naturalisation and Immigration Service } \\ \text { IOM } & \text { International Organization for Migration } \\ \text { IRPP } & \text { Irish Refugee Protection Programme } \\ \text { MRCI } & \text { Migrant Rights Centre Ireland } \\ \text { NASC } & \text { Irish Immigrant Support Centre } \\ \text { NERA } & \text { National Employment Rights Authority } \\ \text { NGO } & \text { Non-governmental Organisation } \\ \text { MIPEX } & \text { Migrant Integration Policy Index } \\ \text { OPMI } & \text { Office for the Promotion of Migrant Integration } \\ \text { SHAP } & \text { UNHCR }\end{array}$




\section{EXECUTIVE SUMMARY}

Illegal employment of non-EU nationals can be defined in two ways, in reference to two different typologies: those who are legally resident working outside the conditions of their residence permit and/or without an Employment Permit, and those who are irregularly resident. ${ }^{1}$ Illegal employment is defined in this study to mean 'economic activity carried out in violation of provisions set by legislation' (European Migration Network, 2014).

Illegal employment is hidden by nature, meaning estimating the scale both in Ireland and within the EU is challenging. According to research by the European Union Agency for Fundamental Rights (2015) high risk sectors tend to be characterised by low wages, long hours and a relatively high turnover in staff. Owing to its hidden nature, illegal employment often impacts upon workers' fundamental rights. Combatting illegal employment is therefore both a social policy and fundamental rights objective, as employees' rights are often violated (European Migration Network, 2017).

This is the first comprehensive study on illegal employment concerning both regularly and irregularly staying non-EU nationals in Ireland, which outlines in detail policy and practice with input from a variety of stakeholders. Its purpose is to provide an evidence base for national and EU policymakers, researchers, practitioners working with non-EEA nationals as well as the general public. The study focusses on policy, law and practice in relation to: prevention measures and incentives for compliance, direct policy initiatives, inspections, sanctions and outcomes for people found to be working illegally.

\section{EU Context}

The illegal employment of non-EU nationals is a concern of the European Union (EU) that intersects with both economic and migration policies. While economic policy is to a large extent a Member State competence, illegal employment of non-EU nationals is nonetheless a policy concern at the European level as it impacts upon irregular migration policy. The European Commission has emphasised that preventing illegal employment is a migration policy objective as the potential for illegal employment is considered to be 'a key pull factor encouraging illegal migration' (European Commission, 2007). In 2009 the EU Employers' Sanctions Directive 2009/52/EC was introduced containing measures

1 The use of the term 'illegal' in the context of irregular migration is disputed by NGOs and others who caution against 'criminalising' this group. See Section 1.7 for a fuller discussion on terminology used within the study. 
to detect and sanction employers who engage in illegal employment, as well as some measures to protect irregularly residing workers. Ireland, UK and Denmark do not participate in this Directive. Ireland's legal migration regime is not significantly influenced by EU policy, including policy on undeclared work.

\section{Characteristics of illegal employment of non-EU nationals in Ireland}

Data on the size of the irregularly resident population, or the extent of illegal employment of non-EU nationals in Ireland, are not currently available from an official or objective source. The NGO Migrant Rights Centre Ireland (MRCl) estimated in 2014 that there were between 20,000 and 26,000 undocumented migrant adults living and working in Ireland and that the vast majority entered the State legally, mainly as students or tourists. MRCl observed that the two most common types of illegal employment seen among clients are students working outside their permitted hours ${ }^{2}$ and migrants without documented residence status. In MRCl's experience undocumented workers are more commonly found in caring positions, particularly in elder care, and in cleaning roles. Workplace Relations Commission officials indicated that issues with illegal employment tend to be more prevalent in the catering sector, including in fast food, takeaways and ethnic restaurants. Businesses with a high turnover of staff, low wages and long hours can indicate increased risk. The Workplace Relations Commission (WRC) performed 4,830 inspections in 2016 and detected 404 possible breaches of the Employment Permits Acts (see below).

A $2016 \mathrm{MRCl}$ survey of undocumented migrants found that five nationalities accounted for 84 per cent of respondents: Filipino (37 per cent of respondents), Chinese (19 per cent), Mauritian (19 per cent), Brazilian (5 per cent) and Pakistani (4 per cent). The majority of undocumented migrants surveyed (61 per cent) were aged between 25 and 39 years.

Official data indicate that during 2015 some 78 alleged victims of human trafficking reported to An Garda Síochána, a 70 per cent increase on 2014 (46). Of this number 23 were alleged victims of trafficking for labour exploitation, of whom ten were non-EEA nationals.

\section{Relevant legislation, outcomes and sanctions}

The legislative framework in the context of illegal work is contained mainly within Employment Permits law: the Employment Permits Act 2003, ${ }^{3}$ the Employment 
Permits Act 2006, ${ }^{4}$ and the Employment Permits (Amendment) Act 2014. Unless their residence permission states otherwise, non-EU nationals may not enter into employment in the State without holding an Employment Permit. Illegal work may also constitute a breach of immigration law: the Immigration Act 1999, as amended, provides that persons who are present within the State without a valid immigration permission, or persons who contravene a restriction or condition of their residence, can be deported. While in theory such persons may be fined and/or lose their residence permission pursuant to Section 3 of the Immigration Act 1999, as amended, INIS has limited experience of such prosecutions.

The study shows that in the context of the illegal employment of non-EU nationals it is more likely that a prosecution would occur under the Employment Permits Acts than under the Immigration Act 1999, as amended. Although the WRC has the power to prosecute both employers and employees, they will usually focus solely on the employer.

The WRC does not routinely pass information regarding non-EU nationals who have permission to reside but who are breaching the conditions of their Employment Permit/residence permit to Gardai/Garda National Immigration Bureau (GNIB). WRC Inspectors report cases of undocumented non-EU nationals to GNIB but this is not the focus of their investigations. This position appears to be in line with the ILO principle that the function of the labour inspectorate is to enforce labour standards and identify breaches of employment law; further duties should not interfere with or deter from this focus. INIS noted that no formalised cooperation takes place between INIS and the WRC regarding inspections; instead WRC cooperates with the GNIB.

\section{Students and illegal employment}

Prior to 2011 the student immigration regime in Ireland was more lightly regulated than today. Students could register annually for Stamp 2 (student) permission to reside without any condition as to the number of renewals. An Interdepartmental Committee on behalf of the Department of Justice and Equality (2010) found evidence of abuse of the system by students and educational providers.

Since 2011 the student regime has been regulated through a number of changes. Perhaps most notably time limits were introduced, which capped the maximum time a non-EU national could remain in the State as a student. The new limits were three years for language or non-degree students and seven years overall as 
a student, including time spent on undergraduate and postgraduate degree programmes. The renewal of student permission became contingent on academic progression and the student work concession became more strictly regulated. Since 2015 the length of the residence permission available to language students was further reduced from one year to eight months, for a maximum of three renewals. The student work concession, under which students can work 20 hours per week in term time and 40 hours per week during holidays without needing to hold an Employment Permit, has also been tightened.

Various measures have been introduced to mitigate the impact of the new restrictions on long-term resident non-EU students, specifically to allow them to maintain legal residence. For example under the two-year Student Probationary Extension introduced in 2012 students who had been registered within the State before January 2005 could apply to reside for two more years as a student, after which period they could apply to reside in the State on a 'Stamp 4' basis with free access to the labour market. Despite the introduction of such measures, research shows that the restrictions did lead to individuals falling into irregularity. As noted above work outside of the concession hours is also still a common feature of student immigration in Ireland.

$\mathrm{MRCl}$ argues that under the historical regime students were seen as contributing to the economy by filling gaps in the labour market and that this view persists in respect of non-degree students.

The Education Strategy 2016-2020 sets targets to increase the number of international students in Ireland, attract outstanding researchers etc. From a policy perspective students are increasingly viewed as participating in the economy in other ways, including by contributing to Ireland's academic institutions (Department of Education and Skills, 2016; The Irish Times, 17 March 2016).

\section{Labour Inspections}

The Workplace Relations Commission (WRC) and An Garda Síochána are the two main national authorities with responsibility for the identification of illegally employed non-EU nationals. The WRC works to ensure compliance with employment law through education and awareness programmes underpinned by focussed, risk-based inspection and enforcement. The WRC conducts an average of 4,500 - 5,500 workplace inspections each year, targeting each sector and industry of employment. The WRC Inspectorate may review shared information from the Department of Social Protection (DSP), the Employment Permits database at the Department of Jobs, Enterprise and Innovation (DJEI), and 
Revenue to identify potential cases for inspection. WRC Joint investigations with Revenue, DSP and Gardaí are undertaken regularly. $\mathrm{MRCl}$ observed that where WRC Inspectors undertake joint inspections with Gardaí, this may undermine the confidence of a non-EU national who is working illegally to report an exploitative employment situation.

During inspections a non-EU national will be required to show evidence of their right to work in the State. Their immigration status is also relevant insofar as it dictates his or her right to work. Inspections are carried out on-site, generally over the course of one business day. An inspector may enter any place of work or premises they reasonably believe is being used as a place of employment of persons or used to keep documents relating to the employment of persons. They may not visit private residences unannounced and should have permission or a warrant from a Court before entering. While WRC inspectors are not required to pre-notify or seek consent from an employer to enter their business premises they generally do so to enable employers to prepare for the inspection and have the relevant records ready for inspection. Inspectors will check that all employees have appropriate permission to work in the State; that information and documentation provided in relation to Employment Permit applications is accurate; and that the conditions attached to the grant of an Employment Permit (such as job description, remuneration, permitted hours of work, etc.) are complied with.

Unannounced out-of-hours inspections are common in the context of joint inspections, where there is deemed to be an increased risk of non-EU nationals being employed illegally. This is due to the WRC view that non-EU nationals working illegally are most often found in sectors and businesses which operate outside of normal business hours e.g. in the catering and restaurant sector. Night/out of hours inspections are usually of a much shorter duration, and depending on the information gathered, a follow-up full-day inspection may be triggered.

Unannounced night inspections were identified by officials from the Workplace Relations Commission as an effective strategy while $\mathrm{MRCl}$ observed that these inspections can result in a punitive reaction from some employers towards workers. It is argued that the inspections may discourage workers from reporting further breaches. Where a compliance issue is identified employers are given the opportunity 'to rectify' issues. $\mathrm{MRCl}$ point out that this can mean that undocumented workers lose their jobs. The ILO (2013) has noted the challenge faced by labour inspectors in regard to irregular migrants, balancing the duty to report back any illicit facts against their role of protecting these workers' rights. The ILO states that the promotion of decent working conditions and 
requirements of national legislation on control of migratory flows needs to be equilibrated in a way to balance conflicting values.'

Policy initiatives which address illegal employment

Several policy initiatives exist which attempt to address illegal employment in Ireland. The reactivation Employment Permit Scheme is available to non-EU workers whose status has become irregular for reasons beyond their control, for example through exploitation. This scheme was identified as positive by $\mathrm{MRCl}$ but long processing times were noted.

The Atypical Working Scheme provides a streamlined mechanism to deal with atypical and short-term work or work not covered by other employment rules. During 2015 concerns were raised about high numbers of undocumented migrants employed in the Irish fishing industry and potential labour exploitation and human trafficking. The Atypical Working Scheme was expanded to include permission for non-EEA workers to work in the Irish fishing fleet in December 2015.

Migrant Rights Centre Ireland (2015) suggests making reforms to the Employment Permit system such as occupation-specific permits rather than employer specific permits; introducing transitional measures for persons between statuses, including Employment Permits; and implementing a regularisation scheme for undocumented migrants (see also Platform for International Cooperation on Undocumented Migrants, 2010). 


\section{SECTION 1}

\section{Introduction}

\subsection{OBJECTIVES AND BACKGROUND TO THE STUDY}

Illegal employment of non-EU nationals ${ }^{5}$ can be defined in two ways, in reference to two different typologies: those who are legally (regularly) resident and those who are irregularly resident. ${ }^{6}$ Illegal employment is defined here to mean 'economic activity carried out in violation of provisions set by legislation' (European Migration Network, 2014). Illegal employment in respect of persons who are regularly staying is defined as employment 'outside the conditions of their residence permit and/or without a work permit' (European Migration Network, 2014). Illegal employment of a person staying in a Member State irregularly is defined for the purposes of this study simply as 'employment of an illegally staying third country national' (European Migration Network, 2014).

The Council of the European Union in 2003 called for the adoption of actions to prevent illegal employment and to improve capacity for measuring the extent of illegal employment (see Section 1.2). The Commission in 2007 emphasised that preventing illegal employment is also a migration policy objective as it is considered to be 'a key pull factor encouraging illegal migration' (see Section 1.2). The illegal employment of non-EU nationals is thus a concern of the European Union (EU) that intersects with both economic and migration policies. The EU, as per Article 79 of the Treaty on the Functioning of the European Union (TFEU), can adopt specific measures to 'develop a common immigration policy' to 'prevent and combat illegal migration'. Member States have an obligation to prevent and combat irregular migration in accordance with EU law (European Migration Network, 2017), such as the 'Return Directive' (2008/115/EC).

Illegal employment is hidden by nature, meaning estimating the scale both in Ireland and within the EU is challenging. Owing also to its hidden nature, illegal employment often impacts upon workers' fundamental rights. Illegal employment is a social policy and fundamental rights objective as employees' rights are often violated (European Migration Network, 2017). According to research by the European Union Agency for Fundamental Rights (2015) high risk

Note that in Ireland nationals of EEA states who are not EU members (Norway, Iceland, Liechtenstein, and Switzerland) are treated similarly to EU nationals in terms of access to the labour market, therefore the term 'non-EU nationals' is taken to also include EEA states who are not EU members.

6 The use of the term 'illegal' in the context of irregular migration is disputed by NGOs and others who caution against 'criminalising' this group. See Section 1.7 for a fuller discussion on terminology used within the study. 
sectors tend to be characterised by low wages, long hours and a relatively high turnover in staff.

The purpose of this study is to outline Ireland's approach to preventing and combatting illegal employment to inform the wider EMN study on the same topic. The synthesis (European Migration Network, 2017) draws on 22 national reports to demonstrate to what degree Member States and Norway have a co-ordinated approach to illegal employment in respect of economic policy and to what degree those policies intersect with EU policies on irregular migration. This report looks at the Irish experience, referring to information from other Member States for comparative purposes.

Section 1 provides an introduction to the study, its objective and scope. Section 1 also discusses the context in which the study is located. Section 2 describes the prevention measures and incentives for employers and employees to avoid illegal employment practices in Ireland. Section 3 looks at specific policy initiatives, which address potential illegal employment mainly by providing clarity and/or flexibility to employers and employees. Section 4 provides information on the identification of illegal employment of non-EU nationals in Ireland. Section 5 outlines the sanctions for employers, regularly and irregularly staying non-EU nationals, and outcomes for non-EU nationals found to be working illegally. Key findings from the study are reviewed in Section 6 .

\subsection{EU POLICY CONTEXT}

In light of Article 5 of the TFEU the Council of the European Union (Council) adopted a resolution calling on Member States to 'examine the common features of undeclared work across the Member States which might best be addressed by a common approach in the framework of the European Employment Strategy' (Council of the European Union, 2003). The Council called for the adoption of actions to prevent illegal employment and to improve capacity for measuring the extent of illegal employment. In 2007 the European Commission (Commission) published a Green Paper on 'Modernising labour law to meet the challenges of the $21^{\text {st }}$ century' to collect stakeholders' views on employment challenges including undeclared work (European Commission, 2006). This was followed by the Commission Communication 'Stepping up the fight against undeclared work', which emphasised that preventing illegal employment is also a migration policy objective as it is considered to be 'a key pull factor encouraging illegal migration' (European Commission, 2007).

It was not until 2009 that legislation that directly targets illegal employment was introduced at the EU level; the Employers' Sanctions Directive 2009/52/EC. The Directive includes measures to prevent, detect and sanction employers who 
engage in illegal employment as well as some measures aimed at protecting irregularly residing non-EU nationals found to be working illegally. The report on the application of the Directive published in 2014 found differences in the approaches taken in sanctioning illegal employment across Member States. Ireland, UK and Denmark do not participate in this Directive. ${ }^{7}$ Ireland's legal migration system (discussed in Section 1.4 below) is largely uninfluenced by EU legal migration policy, including the policy on undeclared work.

The Commission, in the EU Action Plan against migrant smuggling (2015-2020), announced that targets would be identified for inspections of economic sectors most exposed to illegal employment. The 2015 EU Agenda on Migration emphasised the need to prevent illegal employment of non-EU nationals by better enforcement of the Employers' Sanctions Directive. In March 2016, the Commission launched the European Platform on Undeclared Work, with the aim of promoting co-operation between authorities and actors to increase Member States' capacity in the area. The Action Plan recognised the particular vulnerability of migrants in this situation.

As stated in Section 1.1, while economic policy is to a large extent a Member State competence, illegal employment of non-EU nationals is nonetheless a policy concern at the European level as it impacts upon irregular migration policy.

\section{$1.3 \quad$ IRISH POLICY CONTEXT}

Certain categories of non-EEA nationals are granted immigration permission to reside in Ireland which conveys full or limited access to the Irish labour market, without the requirement to hold an Employment Permit (discussed in Section 2). This study is mainly concerned with two categories of non-EU national: persons who have a right to reside, but not a right to work or restricted access to the labour market, and persons who do not have a right to reside.

Non-EEA nationals granted permission to reside on a Stamp 3 or Stamp 0 basis, including certain non-EEA family members and persons of independent means, do not have the right to access the Irish labour market. However Stamp 3 holders may subsequently apply for an Employment Permit and transfer to a Stamp 1. Persons who reside on a Stamp 3 or 0 basis may be found to be illegally working though legally resident.

Ireland may notify the President of the Council in writing, within three months after a proposal or initiative has been presented to the Council pursuant to Title V of Part Three of the Treaty on the Functioning of the European Union, that it wishes to take part in the adoption and application of any such proposed measure, whereupon that State shall be entitled to do so. 
International Students resident on a Stamp 2 basis are permitted to avail of the student work concession. This allows non-EEA students attending a full-time academic programme listed on the Interim List of Eligible Programmes (ILEP) ${ }^{8}$ to work 20 hours per week during term time and up to 40 hours per week during college holidays (see Section 1.6.1). This category of international students may be found to be working outside of the student work concession hours. $\mathrm{MRCl}$ observed that one of the most common examples of persons working irregularly with regular status is students working beyond the 20 hours they are entitled to work during term as per their student permission (see Section 3). ${ }^{9}$ A small number of people are also registered on a Stamp 2A basis. This is a student residence permission that does not provide access to the labour market. It may be issued, for example, to family members of PhD students (the only group of students who, in exceptional circumstances, may be entitled to family reunification). ${ }^{10}$

International non-EEA students attending courses of study not recognised by the Department of Education and Science (resident on a Stamp 2A basis) are not permitted to avail of the student work concession. Persons who fall within this student category may also be found to be working illegally while legally resident.

The second category of interest for this study is persons who are both irregularly present in Ireland and who are engaged in illegal employment, often referred to as undocumented migrant workers (see Section 1.6.2).

International protection applicants are not entitled to access the labour market ${ }^{11}$ and are thus also of relevance to this study though they do not fall within the regularly resident nor the irregularly resident typologies. ${ }^{12}$

\subsection{IRISH LEGAL FRAMEWORK}

Ireland does not participate in the Employer Sanctions Directive (2009/52/EC). Ireland's legislative framework in respect of illegal employment comprises the Employment Permits Act 2003, ${ }^{13}$ the Employment Permits Act 2006, ${ }^{14}$ the

INIS, 'Interim List of Eligible Programmes (ILEP)', www.inis.gov.ie.

Interview with Migrant Rights Centre Ireland, January 2017.

Comments received from INIS, June 2017.

International Protection Act 2015, Section 16 (3)(b).

Applicants are given a permission to remain in the State for the sole purpose of the examination of their application. International Protection Act 2015, Section 16(1).

Amended by the Employment Permits Act 2006 and the Employment Permits (Amendment) Act 2014.

Amended by the Employment Permits (Amendment) Act 2014. 
Employment Permits (Amendment) Act 2014 and the Immigration Act 1999, as amended. $^{15}$

Unless their residence permission states otherwise, non-EU nationals are prohibited from entering into employment in the State, without holding an Employment Permit pursuant to Section 8 of the Employment Permits Act 2006.

Section 2(4) of the Employment Permits Act 2003 as amended places an onus on the employer of a non-EU national to carry out reasonably thorough checks in order to be satisfied that a prospective employee does not require an Employment Permit, or that where an Employment Permit is required, one has been obtained. Applications for Employment Permits act as notification by the employer to the Department of Jobs, Enterprise and Innovation where the nonEU national is Employment Permit required. ${ }^{16}$ Employment permit holders are required to notify the Employment Permit Unit in the event that there is a change to the terms and conditions of the employment in respect of which the Employment Permit was granted (e.g. shorter working week, change in location); to do otherwise could impact negatively on the renewal of their Employment Permit. $^{17}$

Pursuant to the Employment Permits Act 2006, as amended non-EU nationals and employers who breach Employment Permits legislation may be subject to fines, sanctions and/or imprisonment (see Section 5).

The Employments Permits (Amendment) Act 2014 introduced a defence in law for undocumented non-EU nationals who had been in an illegal employment situation through no fault of their own (see Section 5). It also provides that an employer should not benefit from an illegal contract of employment and that the individual who provided the work or services to such an employer should be entitled to some redress notwithstanding the illegality of the contract. The changes brought in by the Employment Permits (Amendment) Act 2014 were welcomed and identified as positive by the Migrant Rights Centre Ireland (Migrant Rights Centre Ireland, 2015d).

The legislative framework in the context of illegal work is contained within Employment Permits law. However the Immigration Act 1999, as amended provides that persons who are present within the State without valid immigration

15 Amended by various acts, including: the Immigration Acts of 2003 and 2005, the Illegal Immigrants (Trafficking) Act 2000 and the International Protection Act 2015.

Interview with INIS, February 2017.

Correspondence with Department of Jobs, Enterprise and Innovation, February 2017. 
permission can be subject to a deportation order requiring them to leave the State within such period as may be specified in the order. Section $3(2)(\mathrm{h})$ of the Immigration Act 1999, as amended, provides that an order may also be made in respect of 'a person who, in the opinion of the Minister, has contravened a restriction or condition imposed on him or her in respect of landing in or entering into or leave to stay in the State'. In order to issue a deportation order to a person who has a legal status in the State, their status must be revoked (Quinn and Gusciute, 2015). Non-EU nationals may also be fined pursuant to the Act of 1999 (see Section 5). INIS noted that, from an immigration perspective, there is generally no distinction between those staying regularly or irregularly who are found to be working illegally; both would be subject to the same removal process (i.e. Section 3 of the Immigration Act 1999). ${ }^{18}$

\subsection{OVERVIEW OF THE MAIN TRENDS REGARDING ILLEGAL EMPLOYMENT IN IRELAND}

Figure 1.1 shows that the total number of valid residence permits ${ }^{19}$ held by nonEEA nationals for the purpose of work was just under 18,000 at end 2015 and 43,540 valid permits were held for education reasons. Permits held for work reasons increased by 13 per cent between 2014 and 2015 (from 15,831 to $17,947)$. The number of permits held for education reasons increased annually from 2012, increasing by 6 per cent between 2014 and 2015 (from 41,225 to $43,540)$. Residence permits held for family reasons also increased annually from 2011, with a small decrease between 2012 and 2013, increasing 11 per cent between 2014 and 2015 (from 23,134 to 25,632). 
FIGURE 1.1 NON-EEA RESIDENCE PERMITS VALID IN IRELAND (NON-EEA NATIONALS AGED 16 AND OVER) 2011-2015

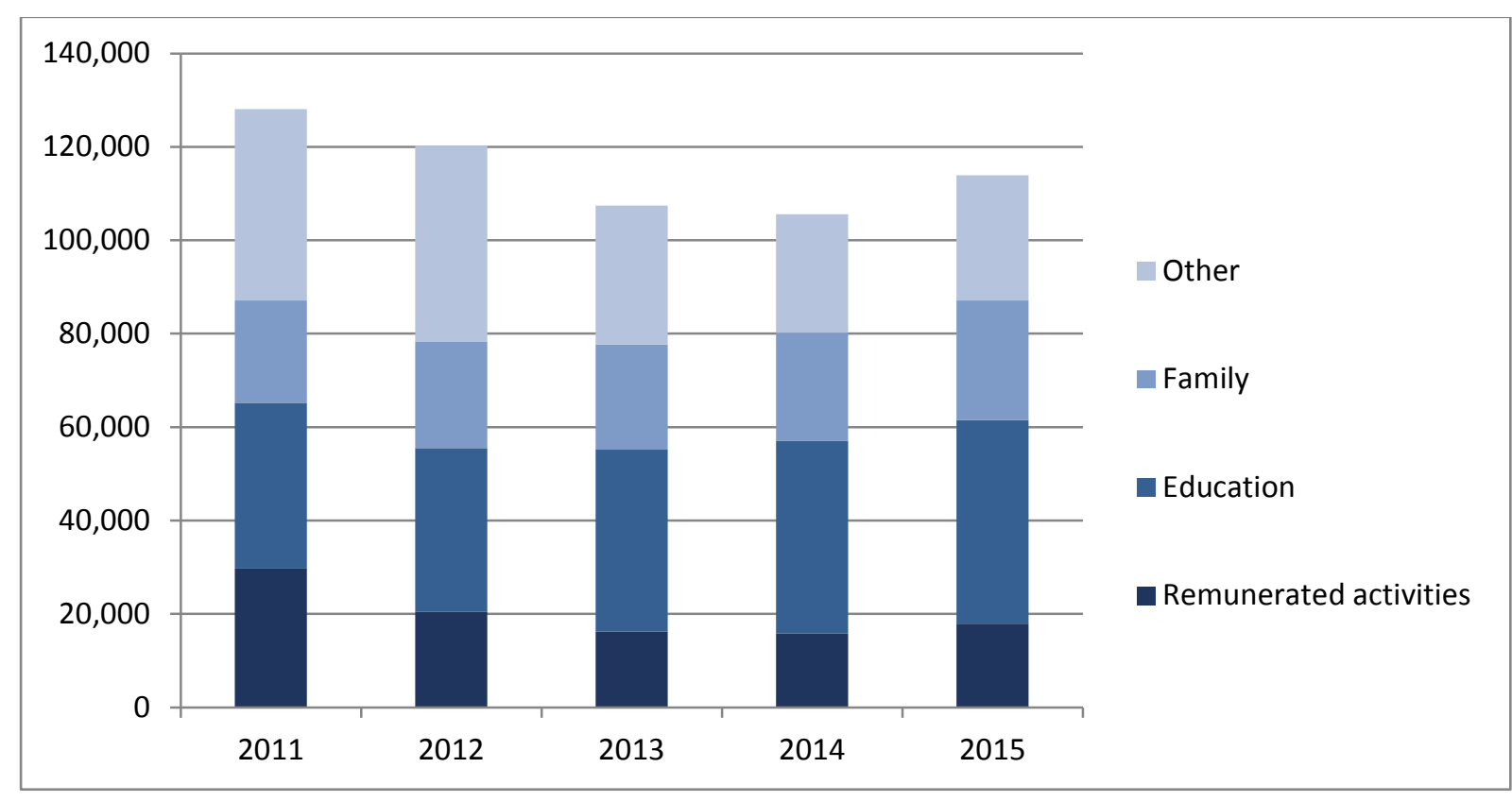

Source: Eurostat [migr_resfas].

$\mathrm{MRCl}$ observed that the two most common types of illegal employment seen among their clients are students working outside the permitted hours (see Section 1.6.1) and undocumented migrants (see Section 1.6.2 below). MRCI also observed that undocumented workers are more prevalent in caring positions, particularly in elder care and in cleaning roles. ${ }^{20}$

The residence permits data therefore provide some information as to: persons in Ireland for work reasons, governed by strict Employment Permit legislation (see Section 5); persons in Ireland for education reasons, governed by student work concession policy, a category of persons deemed at risk of illegal work; and persons in Ireland for family reasons (who may have restricted access to the labour market), some of whom may have joined family for caring purposes.

Data on the extent of illegal employment of non-EU nationals are not available. Data are available on breaches of Employment Permit legislation. Data are also available from the $\mathrm{MRCl}$ relating to undocumented workers (see Section 1.5.2) and student workers (see Section 1.6.1) in breach of their residence permit conditions. It is intended that the data presented below on breaches in Employment Permit legislation and undocumented and student workers provide some, albeit partial, insight into illegal employment in Ireland and the key themes 
and challenges. Section 1.7 provides further insight by looking at other risk areas identified by key stakeholders and the literature.

\subsubsection{Employment Permit breaches}

In 2011 the National Employment Rights Authority (NERA), which is now part of the Workplace Relations Commission (WRC) conducted an analysis across six weeks of their inspections in relation to compliance with Employment Permits legislation. They inspected 441 employers in this period and found 88 employers to be in breach of the Employment Permits Acts. Their report also provided a disaggregation of the profile of non-EU nationals found working in breach of the Employment Permits Acts. Table 1.1 shows that the majority of breaches were by EU nationals; Romanian and Bulgarian nationals, who were working without Employment Permits. A government decision of 17 July 2012 ceased the restrictions on access to the Irish labour market for Romanian and Bulgarian nationals (National Employment Rights Agency 2013).

Of the 212 persons found to be in breach of the Employment Permits Acts, Table 1.1 shows that 15 per cent (31 out of 212) were international students and 9 per cent (9 out of 212) were asylum seekers. Other migrants accounted for 36 per cent, or 77, of the total persons employed in breach of the Acts in 2011.

TABLE 1.1 PROFILE OF PERSONS EMPLOYED IN BREACH OF EMPLOYMENT PERMIT ACTS (1 OCT 2011 - 15 NOV 2011)

\begin{tabular}{|l|c|}
\hline Type & Number \\
\hline EU nationals working without Employment Permit & 85 \\
\hline Asylum seekers working illegally & 19 \\
\hline International students on Stamp 2 working in excess of permitted hours & 31 \\
\hline Other migrants detected working without Employment Permit & 77 \\
\hline Total persons detected working illegally & $\mathbf{2 1 2}$ \\
\hline
\end{tabular}

Source: NERA, 2012.

NERA noted that the sample period for this analysis - 1 October 2011 to 15 November 2011 - included a high number of night inspections of businesses (particularly in the services sector) which would have a higher proportion of migrant workers. NERA cautions that as it is reporting on a limited sample, the statistics presented should be regarded as illustrative rather than definitive (National Employment Rights Authority, 2012).

Since 2012 NERA, and subsequently the Workplace Relations Commission (WRC) (see Section 2), has reported in annual reviews the numbers of suspected 
breaches of Employment Permits legislation which had been detected in the course of their inspections during the year. Table 1.2 shows that between 2014 and 2016 there was a decrease in the number of inspections where breaches of Employment Permits legislation have been detected: 600 breaches were detected in 2014, 429 breaches in 2015 and 404 in 2016 (National Employment Rights Authority, 2015; Workplace Relations Commission, 2015; Workplace Relations Commission, 2016).

TABLE 1.2

SUSPECTED BREACHES OF EMPLOYMENT PERMITS LEGISLATION 2011-2016

\begin{tabular}{|c|c|c|}
\hline Year & Total Inspections & Possible breaches of EP Acts detected \\
\hline 2011 & 5,591 & NA \\
\hline 2012 & 4,689 & 472 \\
\hline 2013 & 5,546 & 453 \\
\hline 2014 & 5,591 & 600 \\
\hline 2016 & 5,185 & 429 \\
\hline
\end{tabular}

Source: National Employment Rights Authority 2012; National Employment Rights Authority 2013; National Employment Rights Authority 2014a; National Employment Rights Authority 2015; Workplace Relations Commission 2015; Workplace Relations Commission, 2016. The 2015 figure displayed combines data compiled by the National Employment Rights Authority (JanuarySeptember 2015) with data compiled by the Workplace Relations Commission (October-December 2015).

NERA commenced reporting statistics on the numbers of calls related to Employment Permits legislation to its information service in 2012. WRC continues to record these figures. The number of calls ranged annually from around 58,000 to around 70,000 between 2012 and 2015 (National Employment Rights Authority, 2012; National Employment Rights Authority, 2013; National Employment Rights Authority, 2014a; National Employment Rights Authority, 2015; Workplace Relations Commission, 2015). Some 28 per cent of the calls recorded by NERA in the period 1 January 2015 to 30 September 2015 were related to Employment Permits (National Employment Rights Authority, 2015).

In both 2013 and 2014, the catering/food and drink sector was the predominant sector in which Employment Permits legislation breaches were found which led to a court imposing a sanction on the employer (National Employment Rights Authority, 2014a; National Employment Rights Authority, 2015). Table 1.3 shows that the number of sanctions imposed by a court increased annually from 2013. There were a total of 71 in 2015, representing an increase of 13 per cent since 2014. 


\begin{tabular}{|c|c|}
\hline Year & Sanctions \\
\hline 2013 & 48 \\
\hline 2014 & 63 \\
\hline 2015 & 71 \\
\hline
\end{tabular}

Source: National Employment Rights Authority 2012; National Employment Rights Authority 2013; National Employment Rights Authority 2014a; National Employment Rights Authority 2015; Workplace Relations Commission 2015; Workplace Relations Commission 2016. The 2015 figure displayed combines data compiled by the National Employment Rights Authority (JanuaryDecember 2015) with data compiled by the Workplace Relations Commission (October-December 2015).

\subsubsection{Undocumented workers}

Data on the size of the irregularly resident population or the extent of illegal employment of non-EU nationals in Ireland are not currently available from an official or objective source. An estimate of the irregular population in Ireland was derived from the Clandestino Project based on extrapolation from UK data. This estimate of 30,000-62,000 in 2008 is marked as 'low quality' (Clandestino Project, 2009).

$\mathrm{MRCl}$ estimated in 2014 that there were between 20,000 and 26,000 undocumented migrant adults living and working in Ireland (Migrant Rights Centre Ireland, 2014b). In $2016 \mathrm{MRCl}$ ran the second wave of a survey of undocumented migrants, originally conducted in 2014. Some 1,008 undocumented migrants from 32 countries were interviewed. The top five nationalities accounted for 84 per cent of those surveyed and were Filipino (37 per cent of respondents), Chinese (19 per cent), Mauritian (19 per cent), Brazilian ( 5 per cent) and Pakistani (4 per cent). The majority of undocumented migrants surveyed (61 per cent) were aged between 25 and 39 years, with 52 per cent female and 48 per cent male. Some 84 per cent of respondents had been living in Ireland for more than five years, with 49 per cent having lived in Ireland for over eight years and 21 per cent for over ten years. A significant majority of those surveyed (89 per cent) were in employment, with 66 per cent having worked for the same employer for over two years and 31 per cent with the same employer for over five years. Just under 70 per cent of respondents worked over 30 hours per week. Some 43 per cent had children aged under 18 (Migrant Rights Centre Ireland, 2016).

The 2014 results indicated that one-third of respondents were currently paying taxes with almost half reporting that they had paid taxes at one time in the past (Migrant Rights Centre Ireland, 2014b). 
In 2016, there were 1,520 entries made in the $\mathrm{MRCl}$ database. ${ }^{21}$ Of these individuals 553 indicated they were undocumented and 511 of these provided further information on their initial status when they entered the State. Of these 511 individuals, 100 per cent entered the country legally, 55 per cent entered the country on a tourist visa while 35 per cent entered the country as a student and 10 per cent entered the country as other. ${ }^{22}$

Overall $\mathrm{MRCl}$ observed that undocumented migrants are over-represented in sectors where there is a high incidence of low pay and exploitation (Migrant Rights Centre Ireland 2015). Research in the area of undocumented migrants highlights the negative impact that irregularity of residence status has on individuals and their families. The research in this area argues that irregularity impacts upon aspects of life other than work, including family life, health services and education (Migrant Rights Centre Ireland, 2007; Migrant Rights Centre Ireland, 2014b; Platform for International Cooperation of Undocumented Minors, 2010).

\subsubsection{Trafficking for the purposes of labour exploitation}

During 2015 some 78 alleged victims of human trafficking reported to An Garda Síochána, a 70 per cent increase on 2014 (46). Some 26 alleged victims, or 29 per cent, were non-EEA nationals. This represents an increase of 229 per cent compared to 2014 where only seven alleged victims of human trafficking were reported. In 2015, 57 per cent (12) of the 26 non-EEA nationals were asylum seekers and only eight per cent (2) had no permission to remain in Ireland. An Garda Síochána received 44 reports of potential victims of trafficking from six non-State groups, four of which work specifically with migrants (Department of Justice and Equality, 2015). ${ }^{23}$ Alleged victims of human trafficking for the purposes of labour exploitation represented 30 per cent (23) of the total (78) in 2015 , some 43 per cent (10) of which were nonEEA. $^{24}$

$\mathrm{MRCl}$ maintains a case management database of persons accessing their services. It has a dual function of capturing data and assisting the management of case files for advocacy purposes. When a person first contacts $\mathrm{MRCl}$, whether by phone, email or in person through the Drop-In Centre a case file is opened with a unique file number. Where a person returns to $\mathrm{MRCl}$ at a later stage, their new query is recorded using their existing case file number. For those who access MRCl's Drop-In Centre, a number of questions are asked in relation to their immigration history, employment history together with information related to health, housing and income. $\mathrm{MRCl}$ clients are free to opt out of answering certain questions. Source: comments received from Migrant Rights Centre Ireland, January 2017. Comments received from Migrant Rights Centre Ireland, January 2017.

23 Immigrant Council of Ireland, Migrant Rights Centre Ireland, Doras Luimní and International Organization for Migration.

24 Comprising: Africa, Asia, non-EEA Europe and other. 


\subsection{OVERVIEW OF IDENTIFIED AREAS AT HIGH RISK OF ILLEGAL EMPLOYMENT}

The WRC indicated that issues with illegal employment tend to be more prevalent in the catering sector, including in fast food, takeaway and ethnic restaurants. ${ }^{25}$ $\mathrm{MRCl}$ observed the area of care in the private home including childcare and elderly carers as high risk for undocumented employment. Ireland does not have a specific immigration scheme for au pairs, such as that proposed as an option under the Student's Directive (2016/801). WRC noted that labelling childcare or domestic workers as au pairs does not exclude them from the same protections of employment legislation as any other worker. This principle has been established in cases taken by persons described as au pairs in both Irish and international jurisdictions. ${ }^{26}$ All childcare workers labelled as au pairs enjoy the same treatment under employment legislation as any other worker. ${ }^{27}$ Furthermore domestic workers are not eligible for Employment Permits except in exceptional circumstances as set out in the Employment Permits (Amendment) Act 2014.

$\mathrm{MRCl}$ campaigns for adequate working conditions and wages for migrant domestic workers including elderly carers and childcare workers known as au pairs, many of whom are irregularly resident and/or working illegally. $\mathrm{MRCl}$ argue that such workers are vulnerable to exploitation including by working long hours for very low pay (Migrant Rights Centre Ireland, 2014a; 2015a; 2015b). Nationals of Brazil (in particular students) and the Philippines comprise a significant proportion of $\mathrm{MRCl}$ clients in childcare and elderly care positions (respectively) (Migrant Rights Centre Ireland, 2015; Migrant Rights Centre Ireland, 2014). ${ }^{28}$

A Eurofound Study (2012) found there was a tendency for ethnic entrepreneurs in Ireland to recruit from their own communities. The report noted this may lead to issues regarding the legal status of their employees, including their right to work in Ireland, particularly as changes to the Employment Permits system have limited employment opportunities for all but the most highly skilled of non-EEA nationals.

\subsubsection{Spotlight on non-EU national students}

Student migration has traditionally been seen as temporary within the Irish migration system: once a student has completed their educational programme they are obliged to leave the State or transition to some other immigration status 
e.g. Employment Permit holder. Time spent in the State as a student is also not reckonable for naturalisation. ${ }^{29}$

Prior to 2011, although students were subject to immigration laws on the same basis as any non-EEA national resident in the State, the student immigration regime in Ireland was less regulated than it is today. Students could register annually for Stamp 2 (student) permission to reside without any condition as to the number of renewals. An Interdepartmental Committee on behalf of the Department of Justice and Equality (2010) found that the pre-2011 system had led to immigration abuse by disreputable colleges and international students motivated to come to Ireland for economic rather than educational reasons. It was argued that such students repeatedly registered for courses in order to continue their residence in Ireland (Department of Justice and Equality, 2010; see also Finn and O'Connell, 2012).

$\mathrm{MRCl}$ expressed the view that a significant section of the current population of irregular migrants in Ireland fell into irregularity following the move from a less regulated international student regime to one that is much more developed. ${ }^{30}$ $\mathrm{MRCl}$ observed that many international students had relatives who entered in the early 2000s when the Irish labour migration regime was more open and relatively laissez faire (Ruhs 2005). ${ }^{31} \mathrm{MRCl}$ observed that some such migrant workers assisted family members to join them and that their experience in a tighter labour market with more stringent Employment Permit controls was quite different. $^{32}$

\section{Time-limits}

The student regime underwent a number of changes from 1 January 2011 onward. The changes were based on suggestions for a 'new immigration regime for full-time non-EEA students' made by the Interdepartmental Committee (Department of Justice and Equality, 2010). The major 2011 reforms included distinguishing between degree and language/non-degree students and imposing time limits on immigration permissions accordingly from January 2011.

Changes introduced in 2011 allowed non-EEA students to spend up to three years in language or non-degree programme and up to seven years overall as a student, including undergraduate and postgraduate degree programmes (Department of Education and Skills and Department of Justice and Equality, 2014). The renewal 
of student permission also became contingent on academic progression. ${ }^{33}$ Since January 2016 the length of the residence permission available to language students has been reduced from one year to eight months, for a maximum of three English language courses and for a maximum period of two years (Department of Education and Skills, 2015). ${ }^{34}$

\section{Work Concession}

In 2014/2015 regulatory reform focused on: restrictions on the programmes permitted for student immigration purposes; an enhanced compliance and inspection regime and strengthening the terms of the student work concession (Department of Education and Skills and Department of Justice and Equality, 2014; Department of Education and Skills, 2015; Sheridan and Whelan, 2016).

Changes introduced in 2015 affected the hours students may work during and outside of term and the holiday entitlements of language students. Students were permitted to work 40 hours per week during the months of May, June, July and August and from 15 December to 15 January. Students could work 20 hours per week during all other times. The student work concession was revised in September 2016 changing the summer work months to June, July, August and September. ${ }^{35}$

\section{Interim List of Eligible Programmes (ILEP)}

An Interim List of Eligible Programmes (ILEP) containing approved higher education institutions and English language providers was published in 2015 and became operational in October of the same year (Department of Education and Skills, 2015). The ILEP replaces the former Internationalisation Register. The ILEP was introduced as a mechanism to combat abuses in the sector and to protect students in two phases. Firstly, further education programmes below NFQ Level $6^{36}$ and all vocational programmes were made ineligible for immigration purposes. ${ }^{37}$ Secondly, from January 2016, English language providers were included on the list after a vetting process involving compliance with certain requirements (Sheridan and Whelan, 2016). ${ }^{38}$ The ILEP guidelines were further reviewed during 2016 and updated criteria and application forms for both Higher

33 INIS, 'Supplementary Guidelines for Degree Programme Students who (a) Wish to change from one degree course to another or (b) Have failed their exams and are seeking extensions to their immigration permission', www.inis.gov.ie. If a student had held one or two 12-month permissions under the old rules, the student can still apply for up to a total of three permissions.

35 INIS, 'Changes to the Employment entitlements of non-EEA students holding Immigration Stamp 2 Student Notices', www.inis.gov.ie.

36 Higher Certificate with 120 ECTS over 24 months at Level 6 of the NFQ is eligible for immigration purposes. Comments received from INIS, June 2017.

37 Ibid.

38 INIS, 'Interim List of Eligible Programmes', www.inis.gov.ie. 
Education and English Language Teaching providers were published in December. INIS generally recommend students to consider the learner protection arrangements ${ }^{39}$ provided by the institution before planning to attend a course of study or indeed pay tuition. Institutions must provide mandatory learner protection in respect of enrolled non-EEA students. ${ }^{40}$ INIS noted that the vast majority of international students (i.e. of EEA nationals or short-term in duration) do not come within the policy remit of the Department of Justice and Equality and therefore the system may not be regulated to the same extent. This was highlighted by INIS as a significant gap in the overall framework for international education in Ireland. ${ }^{41}$

The changes to the holiday entitlement of language students changed in line with the closer regulation of tuition times and hours, conditions associated with inclusion on the ILEP. Language courses must consist of a minimum of 25 weeks tuition at a minimum of 15 tuition hours per week, between 9.00 and 17.00 Monday to Friday. Language courses must take place within eight months. Holiday weeks cannot be front-loaded and can never exceed one-third of the overall eight-month period (Irish Nationalisation and Immigration Service and Department of Education and Skills, 2016 (updated); Department of Education and Skills, 2015). INIS noted that these changes reflect the fact that the primary activity of persons admitted as students is to engage in full-time education and that access to all other activities, including the labour market, should be ancillary to that. ${ }^{42}$

\section{Finance}

From April 2011 all non-EEA students had to show that they had access to $€ 7,000$ upon first registration with the Garda National Immigration Bureau (GNIB). ${ }^{43}$ This was revised in September 2016; non-EEA students must show a minimum level of $€ 3,000$ on first registration. ${ }^{44}$ In addition the annual cost of registration for all non-EEA nationals increased from $€ 150$ to $€ 300$ at the end of 2012 (Gilmartin et al., 2016). ${ }^{45}$ purchased. A student may be offered the course elsewhere or to have their fee reimbursed. Note that learner protection arrangements cover immigration-required non-EEA nationals only. Department of Justice and Quality, May 2017 and Comments received from INIS, June 2017. INIS, 'Interim List of Eligible Programmes', www.inis.gov.ie.

Comments received from INIS, June 2017.

Ibid.

Citizens Information, 'Immigration rules for full-time non-EEA students', www.citizensinformation.ie. INIS, 'Notice Regarding Evidence of Finances for all Non-EEA Students', www.inis.gov.ie.

An Garda Síochána, 'Immigration: Garda National Immigration Bureau', www.garda.ie. 


\section{Continuing challenges}

Various measures have been introduced to assist students who were affected by the time limits and other changes to the student immigration system, such as a two-year Student Probationary Extension for students who have been resident within the State and registered as a student before 1 January 2005. They are discussed in Section 3.4. Despite these changes and the measures implemented to assist students who arrived to Ireland and registered under the old regime, research shows that work outside of the concession hours is still a feature of the international student regime in Ireland (see below).

Research shows that employment is an increasingly important part of international students' lives (Raghuram, 2013). While there is limited research and data on third-level international student employment in Ireland, research on Chinese students in Ireland shows that they often work outside the student concession hours (Pan, 2011). Smith highlighted that childcare workers known as au pairs (see Section 1.6) often came to Ireland on student permits, but became au pairs due to a lack of other employment options and the need to finance their studies (Smith, 2015). McPhee also found that low-skilled workers in service sectors in Dublin also had student permissions. Gilmartin et al. (2016) points out that these areas of work are all low pay with high levels of risk due to their unregulated nature (Gilmartin et al., 2016). The authors argue that the areas of employment are those that have experienced a decrease in Employment Permits (Gilmartin et al., 2016), yet fall within the sectors in which vacancy shortages have been identified by the Nationals Skills Bulletin (SOLAS, 2015).

Reforms to the international student regime were introduced to reduce the likelihood that students would fall into irregularity and reduce illegal work amongst the student population. Gilmartin and $\mathrm{MRCl}^{46}$ argue that international students, particularly those who are not in degree-level education, may still fall into irregularity given new student permission renewal policies (Gilmartin et al., 2016), specifically arising from the requirement for academic progression and the timelines.

\section{Attracting international students to Ireland}

Separate to the changes in the regulation of student hours and the length of time students may stay in Ireland with student permissions, a number of initiatives were introduced from 2010 onward, targeting international students with the aim of bringing them to Ireland (Department of Education and Skills, 2010; Department of Education and Skills, 2016). The Education Strategy 2016-2020

46 Interview with MRCI, January 2017. 
sets targets to increase the number of international students in Ireland, attract outstanding researchers, building international networks with a view to attracting outside funding, equip Irish learners to compete internationally, maximise mobility opportunities of Irish students and enhance global alumnus networks, etc. (Department of Education and Skills, 2016). Gilmartin et al. (2016) note that the 'impact of this strategy can be seen in the growth of International student migration to Ireland, particularly from outside the EEA' (see also The Irish Times, 17 March 2016; Department of Education and Skills, 2016).

The role of students in the Irish economy has changed in Ireland. $\mathrm{MRCl}$ argues that under the historical regime students were seen as filling a gap in the economy, namely the labour market, and that a similar view persists today for non-degree students. ${ }^{47}$ Students in Ireland today, at least from the policy perspective of the Department of Education and Skills, are increasingly viewed as participating in the economy in other ways, including by contributing to Ireland's academic institutions (Department of Education and Skills 2016; The Irish Times, 17 March 2016). INIS noted that the policy imperative of the Department of Justice and Equality is to facilitate non-EEA nationals who intend to study fulltime in Ireland; access to the labour market is viewed as a concession to assist students to finance their studies and to meet high fees. ${ }^{48}$

\subsection{METHODOLOGY}

The information used to produce this report was gathered according to commonly agreed European Migration Network (EMN) specifications developed to facilitate comparability across countries. The $\mathrm{EMN}^{49}$ is tasked with producing studies on topics of relevance to policymakers at national and EU levels, in order to meet long and short-term information needs. Topics may be proposed for indepth strategic studies with long-term relevance, or for shorter studies, responding to immediate information needs. Each EMN National Contact Point produces a national report, and a comparative EU-level synthesis report is then produced, which brings together the main findings from the national reports and places them within an EU perspective. ${ }^{50}$

This study collates data and information on national and EU policy, practice and legislation in the area of illegal employment. Its purpose is to provide an evidence base for national and EU policymakers, researchers, practitioners working with non-EEA nationals as well as the general public. Research on illegal employment in Ireland is sparse. The majority of the literature in Ireland focusses on the 
fundamental rights of vulnerable migrants who find themselves in situations of irregularity (see Section 2). This is the first comprehensive study on illegal employment concerning both regularly and irregularly staying non-EU nationals in Ireland, which outlines in detail policy and practice with input from a variety of stakeholders (see below). Furthermore this study takes account of recent legislative changes in the areas of Employment Permits and the Atypical Working Schemes.

This study focuses on the illegal (either totally or partially undeclared) employment of the following categories of non-EU workers: those regularly residing who are working illegally or who contravene restrictions on their access to labour market; and those irregularly residing, i.e. persons who do not, or do no longer, meet the conditions to stay in the country. Illegal employment of non-EU nationals carrying out self-employment is not covered.

The use of the term 'illegal' in the context of irregular migration has been criticised for 'criminalising' irregular migrants. NGOS such as PICUM argue that the term is incorrect, as being undocumented is not a crime in most countries, and misleading in that most cases of irregular immigration status are caused by exploitation, misinformation or administrative delay (Platform for Undocumented Migrants, 2014). Here we adopt the terminology used in the study specifications and synthesis report and refer to 'illegal employment' as economic activity carried out in violation of provisions set by legislation, and 'irregular' residence or immigration status.

Desk research was undertaken at the outset of the study, including a review of existing academic and policy-based literature. A large amount of information was obtained from government publications and websites, in particular from INIS and the Workplace Relations Commission. National data on Employment Permit breaches were obtained through NERA and WRC. Some national and EU residence permit data were obtained through Eurostat. Data on undocumented migrants were provided by $\mathrm{MRCl}$.

Interviews were undertaken with officials from NERA, WRC, INIS, DJEI, AntiHuman Trafficking Unit (AHTU) and $\mathrm{MRCl}$. Outstanding information gaps were filled with comments from INIS, as well as from $\mathrm{MRCl}$. It was not possible to interview GNIB for the study. The report was internally and externally reviewed. 


\section{SECTION 2}

\section{Prevention measures and incentives aimed at combatting illegal employment}

Section 2 outlines policy and practice aimed at combatting illegal employment in Ireland, including prevention measures.

\section{$2.1 \quad$ INTRODUCTION}

The WRC Inspectorate observed that non-EU nationals represent a hidden and hard to reach population. This can be due to language barriers. It may also be due to their lack of knowledge of their employment rights and obligations under Irish employment law and the relevant agencies (e.g. WRC) who can offer assistance. According to research by Migrant Rights Centre Ireland (2015) non-EU nationals have a relatively high knowledge of the employment rights and entitlements under Irish law. The difficulty arises in seeking enforcement of those rights as they may fear losing their jobs.

As emphasised by the Council of Europe in the 2003 resolution on undeclared work there are various ways to prevent illegal employment before it starts; by providing adequate information, using regular inspections (see Section 4), incentivising employers and employees, and providing clarity and flexibility in terms of law (see Sections 3 and 5) and policy initiatives (discussed in this section) (Council of the European Union, 2003). Section 2.2 provides information on the responsible authorities. Section 2.3 looks at the provision of information and awareness raising initiatives.

\subsection{NATIONAL AUTHORITIES WITH RESPONSIBILITY FOR ILLEGAL EMPLOYMENT}

The WRC and An Garda Síochána are the two main national authorities with responsibility for the identification of illegally employed non-EU nationals. The WRC was established on 1 October 2015 as provided for in the Workplace Relations Act 2015. It has responsibility for information provision, workplace advice, mediation, conciliation, adjudication, inspection, and enforcement in relation to employment rights, equality and equal status matters, and industrial relations. The WRC assumed the roles and functions previously carried out by the National Employment Rights Authority (NERA), Equality Tribunal (ET), Labour Relations Commission (LRC), Rights Commissioners Service (RCS) and some functions of the Employment Appeals Tribunal (EAT). The WRC strives for compliance with employment law through proactive education and awareness 
programmes underpinned by focussed and risk-based inspection and enforcement (see Section 4). ${ }^{51}$

As of January $2016^{52}$ the staff of the WRC Inspection Services numbered around 70 'full-time equivalent' posts. The posts comprise a Principal Officer, solicitor, Assistant Principals, Higher Executive Officer Support, Clerical Admin Support and about 56 Inspectors. The Principal Officer, Solicitor and Assistant Principals perform managerial functions across the Inspection and Enforcement Division and the Information and Customer Division. They have additional duties in the Information and Customer Division, dealing with phone queries and processing complaints for hearing by adjudicators.

An Garda Síochána has personnel, forming part of the Garda National Immigration Bureau (GNIB), specifically dealing with immigration in every Garda district, at all approved ports and airports, and at a border control unit attached to Dundalk Garda Station. In a 2013 study An Garda Síochána emphasised that it welcomes information concerning possible breaches of Employment Permits legislation (Cronin, 2013).

\subsubsection{Co-operation between national authorities}

The Workplace Relations Act 2015 in Section 34 provides that the WRC 'endeavour to secure co-operation between the [WRC] and official bodies' for the purposes of facilitating administrative co-operation, avoiding duplication and sharing information relevant to the employment of persons.

Section 31 of the Workplace Relations Act 2015 also enables information sharing between the WRC and official bodies. ${ }^{53}$ Section 32 of the Act of 2015, drafted in line with Section 8 of the Data Protection Act 1988, allows the exchange of information obtained in the performance of official functions, where there is suspicion that an offence has been committed involving an official body.

51 Written Answer No 59325 October 2016 Department of Jobs, Enterprise and Innovation Workplace Relations Commission, www.kildarestreet.com.

53 Pursuant to Section 2 of the Workplace Relations Act 2015 'official body' means: the Garda Síochána, the Revenue Commissioners, a Minister of the Government, the Director of Corporate Enforcement, the Health and Safety Authority, the Private Security Authority, the Road Safety Authority, the Pensions Authority, the Pensions Ombudsman, the Competition and Consumer Protection Commission, a local authority, the Labour Court, the Employment Appeals Tribunal, the Health Information and Quality Authority, or any other person charged by law with the detection, investigation or prosecution of offences. 
Section 35 of the Workplace Relations Act 2015 enables the WRC to enter into cooperation and data sharing agreements with official bodies, including foreign statutory bodies. ${ }^{54}$ The first such co-operation and data sharing arrangement has been established through a Memorandum of Understanding (MOU) with the Gangmasters Licensing Authority in the UK. The MOU contains provisions in relation to corporation in three areas, information sharing, training and joint inspections. It is planned that further co-operation agreements of a similar nature will be signed in due course. ${ }^{55}$

The strong interagency co-operation in the Irish model as observed by officials from the WRC allows for exchanges of information between official bodies leading to better coverage and detection of instances of non-compliance with employment, tax, social protection and other legislation. Having working ties with the GNIB was also identified by the WRC as a strength as it facilitates awareness raising among inspectors of the indicators of trafficking in human beings. As a result such cases have been referred directly to the GNIB from the WRC. ${ }^{56}$ Cooperation with non-State actors, in particular $\mathrm{MRCl}$, was also identified as an example of good practice. ${ }^{57}$ The EMN Synthesis report arising from this Study also noted that most national templates included co-operation and collaboration as important features of an effective system to combat illegal employment (European Migration Network, 2017).

\subsection{INFORMATION, AWARENESS AND SUPPORT}

No distinctions are made between irregularly staying and illegally working non-EU nationals, and regularly staying and illegally working non-EU nationals, in respect of preventative measures and incentives for employers. ${ }^{58}$ Information and awareness raising initiatives are undertaken regularly and by a variety of different State actors to encourage compliance with Employment Permits legislation. For example the Employment Permits Unit of the Department of Jobs, Enterprise and Innovation provides presentations on the Employment Permits regime and initiatives at various fora. ${ }^{59}$

The WRC provides employment law presentations to stakeholders including employers and sectoral bodies, providing almost 30 presentations to date. ${ }^{60}$ The WRC also provides general information on employment law, equality and 
industrial relations to both employers and employees in line with the provisions of the Workplace Relations Act 2015. Information is available on their website in 14 languages for persons, including non-EU nationals, coming to Ireland to undertake employment opportunities and the requirements with which they must comply. ${ }^{61}$ The WRC identified as challenges the accessibility of the information and translations of information on the website. ${ }^{62}$ In addition the WRC operate an impartial telephone hotline information service (Workplace Relations Commission, n.d.).

NERA published two leaflets setting out basic information on who can take up employment opportunities in Ireland and information on Employment Permits (National Employment Rights Authority, n.d.) and information about employment rights generally (National Employment Rights Authority, 2014b). The aim of these interventions is to provide both employers and employees with information to ensure compliance with employment rights and industrial legislation (Workplace Relations Commission, n.d.). The WRC developed a card with $\mathrm{MRCl}$ which contains information in multiple languages. The card invites people to contact NERA/WRC to discuss their employment rights in confidence. It is used by WRC Inspectors who distribute it to persons for whom English is not their first language. ${ }^{63}$

Education in Ireland, $^{64}$ an umbrella organisation responsible for running information campaigns to attract non-EEA students in Ireland, participates in several international education fairs each year - including in India, Saudi Arabia, Oman, Nigeria and Malaysia. These fairs enable prospective international students to meet representatives of Education in Ireland and Irish universities and higher education institutions. Education in Ireland disseminates information to these prospective non-EEA students about studying in Ireland, including information on the possibility to work in the State without requiring an Employment Permit, 20 hours per week during term time and 40 hours per week during the holiday period (Education in Ireland, 2016).

The Citizens Information Board, the statutory body charged with providing comprehensive information on public services and entitlements in Ireland amongst other duties, hosts information on its website, supports a network of Citizens Information Centres and provides a telephone service. Citizens Information provides information on employment law issues, including compliance with Employment Permits legislation and the various routes through

Workplace Relations Commission, 'Coming to Work in Ireland', www.workplacerelations.ie. Interview with Workplace Relations Commission Inspectorate, January 2017.

Interview with officials from the Workplace Relations Commission Inspectorate, January 2017.

Education in Ireland, www.educationinireland.com. 
which non-EU nationals may legally access the Irish labour market (e.g. as international students).

A number of NGOs active in the migrant sector also provide information services, either through a telephone service or a drop-in centre where non-EU nationals may speak directly to an information officer/case worker. ${ }^{65}$

In addition the WRC answers queries and co-operates with international actors such as the equivalent labour inspectorates in other jurisdictions through the International Labour Organization and EU co-operation mechanisms in relation to Irish practice and employment compliance requirements. Responses may include the provision of existing materials and publications on WRC practices, data exchange, staff exchange and technical assistance. ${ }^{66}$ 


\section{SECTION 3}

\section{Policy initiatives which address illegal employment}

Section 3 looks at specific policy initiatives, which address potential illegal employment directly or indirectly. These initiatives mainly provide clarity and/or flexibility to employers and employees.

\subsection{INTRODUCTION}

Section 3 looks at incentives for employers and employees, and initiatives aimed at facilitating access to Employment Permits, which could be viewed as a prevention mechanism. Sections 3.1 to 3.4 look at targeted interventions aimed at preventing illegal employment and exploitative work practices involving undocumented workers. Section 3.5 looks at trafficking while 3.6 sets out examples of initiatives operating within the Employment Permit system as revised under the Employment Permits (Amendment) Act 2014. Lastly, Section 3.7 looks at other avenues available to non-EU nationals to regularise their status under the wider immigration system.

\subsection{REACTIVATION EMPLOYMENT PERMIT SCHEME}

The Reactivation Employment Permit scheme is limited to persons who entered the State legally and at one point held an Employment Permit and, through no fault of their own they no longer have a valid Employment Permit. The advantage of this Scheme is that it offers a route to an Employment Permit without the prospective employer having to conduct a Labour Market Needs Test and the salary threshold is set at National Minimum Wage or above. Reactivation Employment Permits may be granted for all occupations except domestic operatives. $^{67}$

INIS highlighted the Reactivation Scheme as an example of co-operation between INIS and the Employment Permits section of the Department of Jobs, Enterprise and Innovation. Non-EU nationals can be referred to this scheme by WRC/Employment Permit section or NGOs (e.g. MRCI). INIS and the Employment Permits section then collaborate on the case to bring the non-EU national back into compliance with immigration law and Employment Permit law requirements. ${ }^{68}$ 
INIS described the Reactivation Scheme as positive in that it provides a pathway for non-EU nationals to regularise their status in Ireland. However INIS noted that these cases are complex and require close scrutiny, contributing to longer processing times. INIS also noted that the processing times are long as they are due to the legislative requirement for a non-EU national to hold a valid immigration permission in the State prior to submitting an application for an Employment Permit. ${ }^{69}$

This Scheme was also identified by $\mathrm{MRCl}$ as a scheme which assisted in the prevention of illegal employment. ${ }^{70}$ However the long processing times were noted by $\mathrm{MRCl}$ who stated that it takes approximately six weeks with the Department of Justice and Equality to obtain temporary immigration permission, including two to three weeks wait for an appointment with the GNIB (in Dublin) to obtain an immigration stamp, before an application for the Employment Permit can be made to the Department of Jobs, Enterprise and Innovation (DJEI). If the application to DJEl is not being processed through the Trusted Partner Initiative (see Section 3.6) it will generally take six weeks. While it is acknowledged that there has been an improvement on previous processing times, the current length of the overall application process can lead people to take up irregular employment whilst awaiting the outcome of their application. ${ }^{71}$

\subsection{ATYPICAL WORKING SCHEME}

The Atypical Working Scheme provides a streamlined mechanism to deal with atypical and short-term work or work not covered by other employment rules. This could include an industry with a skills shortage, an internship and other roles, for example locum doctors who are employed and paid by an agency, and nurses and midwives undertaking the Clinical Adaptation and Assessment Programme or Royal College of Surgeons in Ireland Examination. ${ }^{72}$

During 2015 concerns were raised in an article published by The Guardian newspaper about high numbers of undocumented migrants employed in the Irish fishing industry and potential labour exploitation and human trafficking. In response the Government established an Inter-Departmental Task Force on nonEEA workers in the Irish Fishing Fleet in November 2015, chaired by the Minister for Agriculture, Food and the Marine. ${ }^{73}$

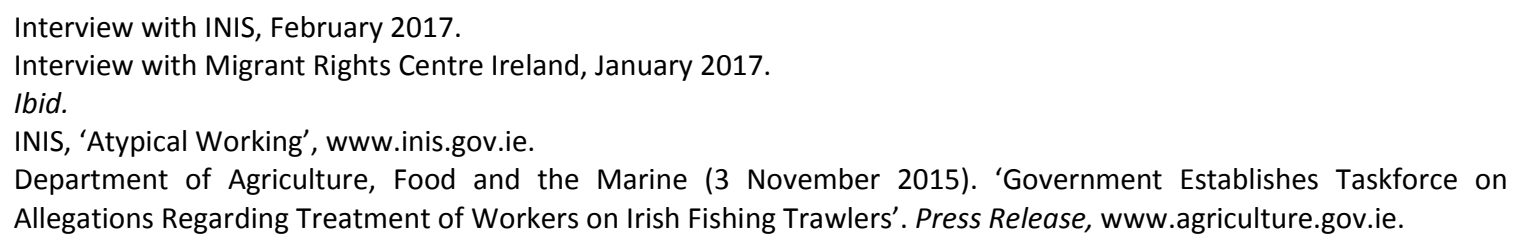


On foot of recommendations of the Task Force the Atypical Working Scheme was expanded to include permission for non-EEA workers to work in the Irish fishing fleet in December 2015. ${ }^{74}$ The number of permissions under this category is capped at 500 and applications have been accepted since 15 February 2016 (Sheridan and Whelan, 2016). INIS indicated that a total of 196 applications had been received as of February 2017, of which 182 have been approved. INIS stopped accepting applications from within the State on 1 July 2016, following which 49 applications have been received. ${ }^{75}$

There was also a further focus in 2016 of cases of labour exploitation occurring in the fisheries sector, particularly in relation to non-EU national fishermen. A Day of Action, 'Operation Egg Shell', took place in October 2016, co-ordinated by An Garda Síochána, the Revenue Commissioners, the Workplace Relations Commission Inspectorate, the Irish Navy and the Sea Fisheries Protection Authority. Some 41 fishing vessels in two Irish Ports were inspected for compliance with employment law, immigration law and the new Atypical Work Permit Scheme. It was carried out as part of the North Atlantic Maritime Project of the Santa Marta Group. The Santa Marta Group is a global alliance to eradicate human trafficking and modern day slavery. It is composed of international police chiefs, bishops and civil society. A number of suspected breaches of the Atypical Working Scheme for non-EEA crew, employment law and immigration law were detected. ${ }^{76}$ Section 4 provides detailed information on inspections, including joint inspections.

\subsection{STUDENT PROBATIONARY EXTENSION}

As discussed in Section 1.6.1, working outside of the student concession was identified as a challenge in the Irish system. Students who breach the concession hours are considered to fall within the 'legally staying, illegally working' category. Section 1.6.1 discussed the recent changes to regulate international student employment. This section sets out the measures implemented to assist students who came to Ireland under the 'old' system.

The Student Probationary Extension was introduced in August 2012 as a measure to assist students transitioning to the new student immigration regime, establishing a seven-year limit on student residence permissions in 2011. Eligibility was limited to students who had been continuously resident in the State from before 1 January 2005 (Joyce, 2014). Eligible students who were granted permission under the scheme during 2012 were registered for a period of

INIS, 'Atypical Scheme: Fishing Crew', www.inis.gov.ie.

Comments received from INIS, March 2017.

Parliamentary Question No. 43, 16 December 2016 Department of Justice and Equality, oireachtasdebates.oireachtas.ie. 
two years on Stamp 2 immigration permission and their status continued to be that of a student. During this period qualifying students were permitted to work up to a maximum period of 40 hours per week without being required to hold an Employment Permit.

As part of the Student Probationary Extension it was indicated that at the conclusion of the two-year probationary period the eligible students could apply for a Stamp 4 permission which would grant them the right to reside in the State and to access the labour market without requiring an Employment Permit or to be self-employed. It is also reckonable towards citizenship and long-term residence. The application process for Stamp 4 permission was undertaken during 2015. The students were not automatically entitled to Stamp 4 permission but had to go through an application process and pay a fee of $€ 1,000$. This fee was outlined in the Immigration Act 2004 (Student Probationary Extension) (Giving of Permission) (Fee) Regulations 2015 (S.I. No. 133 of 2015).

The continuation of Stamp 2 permission for certain students also allows for persons to secure a job offer in order to transfer to Stamp 1 by way of an application for an Employment Permit. ${ }^{77}$ Applications from legally resident spouses of Student Probationary Extension permission holders were considered after their student's application was finalised. ${ }^{78}$ The Student Probationary Extension was identified by $\mathrm{MRCl}$ as a scheme which assisted in the prevention of illegal employment. ${ }^{79}$

While these changes aimed to combat abuse in the sector and protect international students, they also serve as measures to prevent persons from becoming undocumented and working illegally. $\mathrm{MRCl}$ have argued, however, that the changes affecting international students have contributed to persons becoming undocumented (see Section 1.6.1) (Migrant Rights Centre Ireland, 2015).

\subsubsection{Student graduates}

The Stamp $1 \mathrm{G}$ immigration stamp for graduates on the Third Level Graduate Scheme was introduced from 1 February 2016 to provide clarity (in the past graduates would have been issued Stamp 2 student permission). The Graduate Scheme is intended to allow graduates to work while remaining in Ireland to seek longer term employment and to apply for an Employment Permit. Graduates with an honours bachelor's degree can work for up to 40 hours per week for 12

\footnotetext{
Interview with INIS, February 2017.

Irish Naturalisation and Immigration Service 'Conclusion of 2004 Student Probationary Extension', www.inis.gov.ie. Interview with Migrant Rights Centre Ireland, January 2017.
} 
months and graduates with an ordinary level bachelor's degree can work for up to 40 hours per week for six months upon receipt of their final college exam results. ${ }^{80}$ From 1 June 2017 the duration of the Scheme for graduates at Level 9 or above of the NFQ has been extended to 24 months and is being phased out for graduates at Level 7 of the NFQ by $2019 .^{81}$

\subsection{HUMAN TRAFFICKING}

Residence permission is available to facilitate non-EEA nationals identified as a suspected victim of Human Trafficking to remain in the State. Under the Administrative Immigration Arrangements, a suspected victim of human trafficking must be identified as such by a member of the Garda Síochána not below the rank of Superintendent in GNIB. The identification is made where there are reasonable grounds for believing that he or she is a victim of an offence under Sections 2 or 4 of the Criminal Law (Human Trafficking) Act 2008 or Section 3 (other than subsections (2A) and (2B)) of the Child Trafficking and Pornography Act 1998.

In such circumstances, a suspected victim of human trafficking may be granted permission to remain lawfully in the State for a period of 60 days (a 'recovery and reflection period') by the Minister for Justice.

Following the 60 days recovery and reflection period, Temporary Residence Permission may be granted in renewable six-month tranches where the Minister is satisfied that:

(a) the person has severed all contact with the alleged perpetrators of the trafficking; and

(b) it is necessary for the purpose of allowing the suspected victim to continue to assist the Garda Síochána or other relevant authorities in relation to an investigation or prosecution arising in relation to the trafficking.

Persons granted Temporary Residence Permission under these arrangements may apply for a change of status under any other scheme. The application will be assessed in accordance with the terms of the particular scheme (Irish Naturalisation and Immigration Service, 2008). 


\subsection{IMPROVEMENTS TO THE EMPLOYMENT PERMITS SYSTEM}

A number of initiatives were introduced to complement the Employment Permits system in order to make the application process more straightforward and encourage compliance. In 2014 the legislation was amended, providing different types of permits for different purposes. The amendments brought in by the Employment Permits (Amendment) Act 2014 took account of the needs of business, for example start-ups, and need in the labour market. The Act of 2014 provides clarity for investors and employers and provides 'the necessary flexibility for key sectors of economic growth' (Gusciute et al., 2015).

An online application system for Employment Permits ${ }^{82}$ was also launched in September 2016 enabling faster turnaround of applications, easier submission of documents and payments. It also provides useful information to guide applicants through the application. It is envisaged that there will be fewer errors and rejected applications. ${ }^{83}$

In 2015 the Trusted Partner Initiative for Employment Permit applications was introduced. ${ }^{84}$ It streamlines the application process for the person making the offer of employment/employer/connected person/EEA contractor. ${ }^{85}$ The Trusted Partner Initiative and the EPOS improve efficiency and clarity, making the application process more straightforward for employers and prospective employees. These mechanisms may reduce reliance on illegal employment to circumvent the applications process.

The Act of 2014 also introduced measures to protect and support the employee (see Section 5). For example, Employment Permit holders who are made redundant have up to six months to find alternative employment and apply for a new Employment Permit. They are exempt from certain rules that would otherwise apply, for example the Labour Market Needs Test and eligibility criteria in relation to the job. ${ }^{86}$

In recognition of the risk of illegal employment and history of abuses in relation to employment rights and Employment Permits legislation in the catering sector, $^{87}$ a number of additional documents are required from prospective employers of non-EU nationals in this sector. ${ }^{88}$ 


\subsection{OTHER OPTIONS FOR REGULARISATION}

It is possible for an undocumented migrant who has regularised his or her residence status to apply for a [General] Employment Permit. The new residence permit must be of a type that allows labour market access (e.g. Stamp 1) and he or she will be expected to comply with all the requirements in order to obtain an Employment Permit.

An undocumented migrant may apply for residence permission for reasons other than employment, for example for family reasons. In this case an undocumented migrant who is a married spouse or civil partner to someone who is legally resident or who is an Irish or EEA national may be issued Stamp 3 or Stamp 4 permission to reside in Ireland as long as the sponsor continues to reside in Ireland. The Stamp issued depends on the status of the partner (Arnold and Quinn, 2017).

$\mathrm{MRCl}$ identifies a number of policy-related barriers that can prevent irregular migrants from regularising their situation including the stringent Employment Permits system (Migrant Rights Centre Ireland, 2015) characterised by the labour market needs test and the Ineligible Categories of Employment List. ${ }^{89}$

A lack of flexibility to switch employers was also cited as a reason why some workers become irregular (Migrant Rights Centre Ireland, 2015), however it was noted that the DJEl has improved the processing of individual cases of concern. Research in Ireland also suggests that discrimination is an issue in the labour market that affects non-EU nationals (see, for example, Kingston et al., 2015).

$\mathrm{MRCl}$ recommends a number of reforms which may prevent illegal employment, including further reforms to the Employment Permits system such as occupationspecific permits rather than employer specific permits; introducing transitional measures for persons between statuses; including Employment Permits; and implementing a regularisation scheme for undocumented migrants (Migrant Rights Centre Ireland, 2015; see also Platform for International Cooperation on Undocumented Migrants, 2010). 


\section{SECTION 4}

\section{Identification of illegal employment through inspections}

Section 4 outlines the inspection process, including information on joint inspections and co-operation with other national authorities.

\subsection{INTRODUCTION}

Section 4 outlines the inspection process in Ireland. It provides information on risk assessments and the source of referrals and complaints that lead to inspections. This section also outlines the procedures followed by key actors in the inspections of places of employment. This section is linked to Section 3 in that inspections and public information on inspections may serve as a prevention mechanism in and of itself. Section 5 looks at the potential consequences to business and individuals if employees are found to be working illegally.

\subsection{OVERVIEW OF INSPECTIONS FRAMEWORK}

All Member States that participated in this study use inspections to identify illegal employment of non-EU nationals (European Migration Network, 2017). Inspectors of the WRC are also appointed as Authorised Officers of the Minister for Jobs, Enterprise and Employment pursuant to Section 22 of the Employment Permits Act 2006 to enforce both the 2003 and 2006 Employment Permits Acts, as amended and they regularly inspect workplaces to ensure compliance with Employment Permits legislation. Inspections for compliance with Employment Permits legislation are carried out in parallel. Inspections may include:

- An examination to ensure that all non-EU national employees have appropriate permission to work in the State;

- An examination of the accuracy of information and documentation provided in relation to Employment Permit applications; and

- Checks that the conditions attached to the grant of an Employment Permit (such as job description, remuneration, permitted hours of work, etc.) are complied with.

In addition, as part of its control and monitoring of Employment Permit applications, the Employment Permits Section selects a random sample of permit 
applications each month for further examination. These are forwarded on to the Workplace Relations Commission for inspection. ${ }^{90}$

The WRC is committed to providing Inspectors with specific language skills. In this regard, Inspectors were recruited who were proficient in a range of languages including Polish, Lithuanian, Czech and Russian, with some Inspectors proficient in multiple languages. ${ }^{91}$ There are currently five Inspectors who are proficient in more than one language. ${ }^{92}$

The WRC conducted an average of between 4,500 and 5,500 inspections each year between 2011 and 2016 (see Table 1.2), with inspections targeting each industry and sector of employment. ${ }^{93}$

\subsection{JOINT INSPECTIONS AND CO-OPERATION}

The WRC Inspectorate may review shared information available from the Department of Social Protection, the Employment Permits database at the DJEI, and Revenue data to identify potential cases for inspection. The WRC Inspectorate may request information from the GNIB (Quinn and Kingston, 2012).

Section 22 of the Employment Permits Act 2006 also provides that WRC Authorised Officers may, if they consider it necessary, be accompanied by other Authorised Officers (Revenue, Social Protection etc.) and/or members of An Garda Síochána (see also Cronin, 2013). Section 22 also provides for An Garda Síochána, in its own right, to enforce the Employment Permits legislation.

Joint Inspections involve the pursuit of agreed priorities, involving analysis of information and experience of the Joint Inspection Unit (JIU) members in order to select areas of interest. For both the Department of Social Protection and Revenue, the JIU structure is a key part of the respective strategies, which derive from Government policy.

Joint investigations with Revenue, DSP and Gardaí are approved locally by the relevant WRC Inspector Team Manager whilst JIUs with other State bodies

Written Answers No 2606 July 2016 Public Sector Staff Data, Department of Jobs, Enterprise and Innovation Available at: www.oireachtasdebates.oireachtas.ie. It was noted by officials from the Workplace Relations Commission that the recruitment of Inspectors with specific language skills was tied to the enlargement of the EU with the addition of Member States from Central and Eastern Europe and the subsequent influx of Eastern European workers to Ireland. Correspondence with officials from the Workplace Relations Commission, February 2017.

Correspondence with officials from the Workplace Relations Commission, February 2017.

Interview with Workplace Relations Commission Inspectorate, January 2017. 
require the approval of a WRC Regional Manager. Prior to the inspection, the various agencies participating in the Joint Inspection liaise to share information and identify each agency's desired outcome. Participating agencies retain their individual powers and as such may only act in accordance with their own legal powers and procedures (Workplace Relations Commission, 2015).

$\mathrm{MRCl}$ observed that where WRC Inspectors undertake joint inspections with Gardaí, this may undermine the confidence of a non-EU national who is working illegally to report an exploitative employment situation to a WRC Inspector. ${ }^{94}$

INIS noted that no formalised co-operation takes place between INIS and the WRC regarding inspections; instead WRC co-operates with the GNIB. ${ }^{95}$

\subsection{SOURCES FOR INSPECTIONS}

The WRC undertakes a general risk assessment as part of the annual planning process for inspections. Risk of breaches of Employment Permits legislation is also taken into account during this process. The risk assessment is based on experience and breach levels within sectors whilst considering contributions and developments from global discourse on the subject of illegal employment, noncompliance with other statutory obligations, information in the public domain and levels of referrals and complaints. ${ }^{96}$ The WRC focuses on 'risk-based enforcement in order to effectively target potential non-compliance and ensure that compliance costs are proportionate to the regulatory outcome' (Workplace Relations Commission, 2015). Within this overall planning framework, sectors which have the highest risk of illegal employment of non-EU nationals are also identified, which may be informed by:

- enforcement referrals;

- JIU inspections;

- unannounced visit follow-ups;

- risk based selection;

- control samples;

- geographical/sectoral projects (Workplace Relations Commission 2015);

- requests from external agencies or in collaboration with cross-European or other international actions; ${ }^{97}$ and 
- requests from other agencies (e.g. Revenue, Department of Social Protection, An Garda Síochána).

As mentioned in Section 1.6 WRC officials indicated that issues with illegal employment tend to be more prevalent in the catering sector, including in fast food, takeaways and ethnic restaurants. Businesses with a high turnover of staff, low wages and long hours can indicate increased risk.

\subsubsection{Complaints}

Those wishing to submit a complaint to the WRC can do so via the telephone information service. Complaints may also be submitted via the Workplace Relations e-Complaint Form, available on the Workplace Relations Commission website. It can be used to submit complaints to the WRC in relation to contraventions of employment, equality and equal status legislation. It is not possible to select contravention of Employment Permits legislation from the drop-down menu contained in the e-Complaint Form but it is possible to add 'new complaint' to the form and add the relevant details prior to submission. ${ }^{98}$

On receipt of the complaint, the WRC acknowledges receipt and forwards it to the appropriate section. Where the complaint is to be dealt with by adjudication, the details of the complaint are forwarded to Employer/Respondent. Inspections may also be triggered from referrals from other official bodies or the general public. Complaints which are to be investigated by means of inspection are referred to the Commission's Inspection Services. ${ }^{99}$

Complaints to the WRC are deemed to be high priority and represent the source of approximately 20 per cent of the total inspections conducted by WRC Inspectors each year. ${ }^{100}$

The NGO PICUM (Platform for International Cooperation on Undocumented Migrants) has developed a set of Guidelines which stress the need for a 'firewall', meaning a clear separation in law and practice between putting forward a complaint to the relevant national body and any proceedings related to immigration (Platform for International Cooperation on Undocumented Migrants, 2016).

\footnotetext{
98 For example, in 2016 there was a focus on 'pop-up' car washes which was co-ordinated and promoted by Europol on a pan-European basis. Interview with Workplace Relations Commission Inspectorate, January 2017. 


\subsection{OVERVIEW OF INSPECTIONS PROCEDURES}

\subsubsection{Information collection}

The WRC has a comprehensive procedures manual for WRC Inspectors, the 'Inspection Service Case Management Procedures Manual' which sets out the pre-inspection process for WRC Inspectors, the procedures in relation to conducting the inspection, checklists for documents to review during the inspection, procedures on interviewing employers and employees and postinspection follow up procedures.

The WRC sets out the procedure for inspecting records in 'Procedure 4.8(2) The Inspection Process - Examining Records'. It places particular emphasis on WRC Inspectors examining the employee records of 'low-paid, migrant or otherwise potentially vulnerable employees' to ensure they have an accurate view of the organisation's level of compliance. The procedure sets a list of documents and records which should be examined as part of the inspection, these include:

- A completed template provided by the WRC (this is sent with the appointment letter) or the same information provided in a similar format;

- Employer Registration number with the Revenue Commissioners;

- Terms of Employment issued by the employer for a sample of employees;

- Payroll details; ${ }^{101}$

- Sample copies of Payslips;

- Annual Leave and Public Holiday entitlements received by each employee;

- Hours of work for each employee (including start/finishing times, meal breaks and rest periods);

- Register of Employees under 18 years of age;

- Experience of workers;

- Whether board and lodgings are provided and relevant details;

- Employment permits or evidence of permission to work for all non-EEA workers; and

- Any other documentation that may be necessary to demonstrate compliance (Workplace Relations Commission, 2015).

Records selected for inspection should be drawn from the 12 months immediately prior to the date of the inspection. Non-EEA nationals will be 
required to show evidence of their right to be work in the State. The immigration status of the person is also relevant to the inspectors insofar as it dictates his or her right to work.

Section 27 of the Workplace Relations Act 2015 allows for the inspectors to inspect and take copies of/remove books, records, documents, etc. and require assistance from any person at the place of work and require them to produce any documents and answer any questions.

Where no records are kept, or the records are not kept in the prescribed form, the Inspector continues with the inspection of the data available and seeks the appropriate information from the employees at the interview stage to determine compliance. The procedure outlines that employee interviews must always form part of the inspection process and employees should ideally be interviewed on the same day as the examination of records (Workplace Relations Commission, 2015). A sample of employees, between three and ten, (depending on the number employed by the organisation), are selected for interview based on criteria such as level of pay and job description (Workplace Relations Commission, 2015). Interviewing the Employer or the Employer's representative in addition to interviewing employees of the organisation also forms part of the inspection process (Workplace Relations Commission, 2015). Any person who is asked questions for the purposes of the inspection must be cautioned by the inspector(s) that anything they say will be written down and may be given as evidence.

\subsubsection{Inspection procedure}

Inspections are carried out on-site, generally over the course of one business day. Section 27 of the Workplace Relations Act 2015 sets out the entry and search powers of labour inspectors. An inspector may enter any place of work or premises they reasonably believe is being used as a place of employment of persons or used to keep documents relating to the employment of persons. (They may not visit private residences unannounced as discussed below.) WRC inspectors are not required to pre-notify or seek consent from an employer to enter their business premises. Generally however, WRC inspectors do pre-notify employers of their intention to inspect their business to enable them to prepare for the inspection and have the relevant records ready for inspection. This is so the inspection can be completed efficiently with minimum disruption to the operation of the business. ${ }^{102}$ 
Where an employer is employing non-EU nationals without fully complying with Employment Permit legislative requirements, the pre-inspection notification may act as a 'tip-off' to the employer so they ensure such employees are not on the premises on the day of inspection. However officials from the WRC Inspectorate noted that in the case of joint inspections with An Garda Síochána, Revenue and the Department of Social Protection they usually follow the unannounced out-ofhours inspection procedures for businesses where the risk of non-EU nationals being employed illegally is higher. ${ }^{103}$ This is due to the view that non-EU nationals working in a manner not in compliance with Employment Permits requirements are most often found in sectors and businesses which operate outside of normal business hours e.g. in the catering and restaurant sector. ${ }^{104}$

Night/out of hours inspections are usually of a much shorter duration than a full day inspection and are intended to provide a quick snapshot of the level of compliance by the employer with employment law requirements. Depending on the information gathered during the 'spot check' inspection, a follow up full day inspection may be triggered. ${ }^{105}$

Unannounced night inspections were identified by officials from the Workplace Relations Commission as an effective strategy used to detect non-EU nationals working without the required Employment Permit. Workers without permission tend to work in sectors where night work predominates and there can be a perception that it is 'safer' to work outside of normal working hours. This results in the detection of non-EU nationals working for non-compliant employers, often on more than one occasion. ${ }^{106}$ The Migrant Rights Centre Ireland disputes the effectiveness of this method of inspection, observing that out of hours inspections can result in a punitive reaction from some employers towards workers. It is argued that the inspections may discourage workers from reporting further breaches. ${ }^{107}$

Where a compliance issue is identified and where the employer fails to rectify the issues within a reasonable period of time, the procedures for escalating the case to the court process are also set out (Workplace Relations Commission, 2015). Migrant Rights Centre Ireland observed the unequal impact of inspections on 
employers and workers: employers are given the opportunity 'to rectify' issues, with the result that undocumented workers may lose their jobs. ${ }^{108}$

As discussed in Section 5.4, WRC Inspectors report cases of undocumented nonEU nationals they detect to GNIB but this is not the focus of their investigations and inspectors do not routinely pass information on regularly resident persons in breach of the conditions of their Employment Permit/residence permit to Gardaí/GNIB. ${ }^{109}$ This position appears to be in line with the ILO principle that the function of the labour inspectorate is to enforce labour standards and identify breaches of employment law; further duties should not interfere with or deter from this focus. ${ }^{110}$ Migrant Rights Centre Ireland reported a perception among migrant workers that some labour inspectors will prioritise the checking of immigration status over employment law compliance. ${ }^{111}$

\subsubsection{Inspections in private dwellings}

In the case of private dwellings, the inspector must have either the consent of the occupier or a warrant issued by a judge of the District Court in order to enter, pursuant to Sections 27 (3) and (4) of the Workplace Relations Act 2015. They may be accompanied by a member of An Garda Síochána when executing the warrant pursuant to Section 27(2) of the Workplace Relations Act 2015. This was identified as a challenge. ${ }^{112}$ However the WRC stated that permission is granted upon request 50 per cent of the time. If the homeowner does not agree to inspection they must present employment records at an alternative venue. ${ }^{113}$ Another issue experienced in this area is that in order to draw a sample of domestic workers, the WRC Inspectorate are limited to checking information relating to domestic workers obtained from Revenue records. Otherwise inspections of domestic homes rely on reports of abuses (Quinn and Kingston, 2012).

\footnotetext{
Comments received from Migrant Rights Centre Ireland, May 2017. Interview with officials from the Workplace Relations Commission Inspectorate, January 2017. ILO Labour Inspection Convention, 1947 (No. 81). Comments received from Migrant Rights Centre Ireland, May 2017. Interview with Workplace Relations Commission Inspectorate, January 2017. Correspondence with Workplace Relations Commission, February 2017.
} 


\section{SECTION 5}

\section{Sanctions and Outcomes}

Section 5 outlines the sanctions for employers, regularly and irregularly staying non-EU nationals, and outcomes for non-EU nationals found to be working illegally.

\section{$5.1 \quad$ INTRODUCTION}

Section 5 outlines the sanctions and penalties deriving from Irish law. Section 5.3 looks at sanctions and penalties in Employment Permits legislation. Section 5.4 looks at the potential outcomes for persons found to be in breach of their residence permits in immigration law. Section 5.5 discusses recourse for persons who have been found to be working illegally through no fault of their own.

\subsection{SANCTIONS AND PENALTIES IN LAW}

As outlined in Section 1.2, all Member States except Denmark, Ireland and the UK have responsibilities in respect of the sanctions for employers of illegal employment of irregularly staying non-EU nationals pursuant to the Employers' Sanction Directive. Measures include financial sanctions, back payments for workers and criminal penalties. In Ireland sanctions, penalties and outcomes for employees and employers are governed by Employment Permits legislation and immigration law.

\subsection{EMPLOYMENT PERMITS LAW}

Various activities are prohibited under the Employment Permits Act 2006, as amended which on conviction can lead to a fine or a term of imprisonment. These include a prohibition on forgery, fraudulent alteration or fraudulent use of an Employment Permit; ${ }^{114}$ the use of the Employment Permit for a different employment; ${ }^{115}$ deduction from remuneration and retention of personal documents. ${ }^{116}$ It is also an offence to knowingly or recklessly furnish misleading information to the Minister. ${ }^{117}$ Fines range from up to $€ 3,000$ to $€ 250,000$, and terms of imprisonment range from up to 12 months to five years depending on whether it is a summary conviction or conviction on indictment. ${ }^{118}$ 
Pursuant to the Employment Permits Act 2006, as amended by the Employment Permits (Amendment) Act 2014 a person who is found to have used an Employment Permit for anything other than its intended purpose (or by anyone other than the intended person) is liable to a fine not exceeding $€ 5,000$ and/or up to 12 months imprisonment or on conviction on indictment, to a fine not exceeding $€ 50,000$ and/or five years imprisonment.

Any person who contravenes the terms of their Employment Permit and/or any employer who contravenes their obligations in respect of Employment Permit legislation shall be found guilty of an offence and may be liable to a fine of a maximum of $€ 3,000$ and/or 12 months imprisonment; or on conviction on indictment, to a fine not exceeding $€ 250,000$ and/or ten years imprisonment.

The Minister or the WRC acting on behalf of the Minister may intervene on behalf or in support of non-EU nationals in relevant administrative or civil proceedings.

The WRC Inspectorate noted that they focus their efforts on employers. This is consistent with practice across Europe (European Migration Network, 2017). Where there has been a breach of Employment Permit legislation, though the WRC has the power to prosecute both employers and employees, they will usually focus solely on the employer. The exception to this general rule is in the case of fraud on the part of the non-EU national employee. ${ }^{119}$

Sanctioning employers who illegally employ non-EU nationals was identified by six Member States participating in this EMN study as acting as a strong deterrent for employers (European Migration Network, 2017).

\subsection{IMMIGRATION LAW}

Illegal work may also constitute a breach of immigration law, although it is uncommon. ${ }^{120}$ The Immigration Act 1999, as amended sets out the legal framework for this process. The Immigration Act 1999 provides for persons to be fined under the Act on conviction of an offence. Section 9 of the Act of 1999 provides: 'A person guilty of an offence under this Act shall be liable on summary conviction to a fine not exceeding $£ 1,500$ or to imprisonment for a term not exceeding 12 months or to both '. 
In order to initiate a returns decision, i.e. to send out a '15-day letter' (see Section 5.4 .1 below), the person's residence permission must be revoked. INIS noted that this is uncommon, though a small number of persons have had their Stamp 0 withdrawn. Most forcible returns involve persons with no status in the State. ${ }^{121}$

As introduced in Section 1, INIS noted that, from an immigration perspective, generally in Ireland there is no distinction between those staying regularly or irregularly who are found to be working illegally; both would be subject to the same removal process (i.e. Section 3 of the Immigration Act 1999) from an immigration perspective. ${ }^{122}$ INIS further commented that, in the context of the illegal employment of non-EU nationals, it is more likely that a prosecution would occur under the Employment Permits Acts than under the Immigration Act 1999, as amended. ${ }^{123}$ However, it remains possible that persons found to be working illegally and/or without current immigration permission could be prosecuted for breaches of the Employment Permit acts while being prosecuted for breaches of the immigration acts. ${ }^{124}$

WRC Inspectors report cases of undocumented non-EU nationals they detect to GNIB but this is not the focus of their investigations. The labour inspectorate does not routinely pass information regarding non-EU nationals who have permission to reside but who are breaching the conditions of their Employment Permit/residence permit to Gardaí/GNIB. WRC takes the position that as regularly staying illegally working non-EEA nationals are not committing an immigration offence, therefore no obligation arises to report to GNIB. ${ }^{125}$

Illustrating this point, as discussed in Sections 1 and 3, MRCI noted that one of the most common examples of persons working irregularly with regular status is students working beyond the 20 hours they are entitled to work during term as per their student permissions. While in theory such persons can be fined and/or lose their residence permission pursuant to Section 3 of the Immigration Act 1999, as amended, INIS has limited experience of such prosecutions. ${ }^{126}$

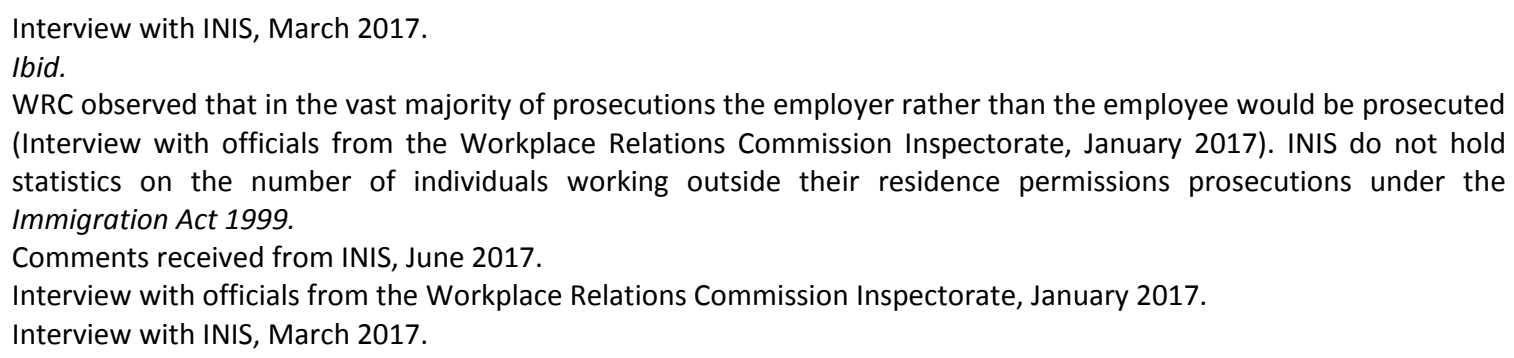
(Interview with officials from the Workplace Relations Commission Inspectorate, January 2017). INIS do not hold statistics on the number of individuals working outside their residence permissions prosecutions under the Immigration Act 1999.

Comments received from INIS, June 2017.

Interview with officials from the Workplace Relations Commission Inspectorate, January 2017.

Interview with INIS, March 2017. 


\subsubsection{Deportation}

The Minister for Justice and Equality may nevertheless issue a deportation order if a person's permission is revoked, or if the person found to be working illegally has no legal status in the State. In this case the Minister pursuant to Section 3 of the Immigration Act 1999, as amended writes to the applicant notifying them of the intention to deport him/her. This is commonly known as a '15-day letter'. The letter contains three options for the person concerned:

- leave the State voluntarily;

- consent to a deportation order being made; or

- make representations, within 15 days, as to why s/he should be allowed remain in the State, including humanitarian considerations (Quinn and Gusciute, 2015, Annex 1). This decision is at the discretion of the Minister for Justice and Equality and there is no substantive appeal.

If issued, the Deportation Order is accompanied by an 'arrangements letter' which constitutes the formal serving of the Deportation Order (Quinn and Gusciute, 2015).

There is no right of appeal against the issuance of a deportation order; an applicant can, however, seek to have the deportation order amended or revoked by the Minister under Section 3(11) of the Act of 1999. The application to amend or revoke the deportation order does not suspend the enforcement of the deportation order.

Applicants may seek a judicial review of a deportation order in the High Court. The judicial review application also does not suspend the enforcement of the deportation order. Where an applicant is in the State and seeking to either revoke or judicially review a deportation order, he/she will be dependent on the Minister giving an undertaking to not enforce the deportation pending determination of the application, or will otherwise need to seek an injunction from the High Court restraining removal pending the determination of the matter.

All deportation orders contain an entry ban of indefinite duration.

\subsubsection{Detention}

Non-EU nationals may be detained while the deportation order is in place. Detention is provided for in Section 5 of the Immigration Act 1999, as amended which enables an immigration officer or a member of An Garda Síochána to 
detain a person against whom a deportation order is in force where they 'with reasonable cause suspect' that person:

- intends to evade removal from the State;

- has destroyed their identity documents or are in possession of forged identity documents;

- intends to leave the State and enter another state without lawful authority; or

- has failed to comply with any of the requirements contained in the deportation order.

Illegal work is unlikely to be the sole reason for detention. ${ }^{127}$

\subsection{RECOURSE FOR EMPLOYEES}

In recent years the exploitation of migrant workers by employers in the State has received attention, much of it centred on the case of Hussein v. Labour Court, ${ }^{128}$ in which the High Court overturned a decision of the Labour Court brought by the employer (the applicant). The Labour Court directed the employer to pay Mohammad Younis (the notice party) wages and other monies due. The High Court overturned the decision of the Labour Court on the basis that the worker's contract of employment was unlawful. The High Court's decision was overturned on appeal to the Supreme Court. ${ }^{129}$ The Supreme Court argued that the High Court could not make a new finding of fact. The Labour Court did not make a finding relating to the applicant's status in the country and eligibility in respect of labour market access. The Supreme Court allowed the appeal and allowed the decision of the Labour Court. The notice party, Mohammad Younis was entitled to the payment of approximately $€ 92,000$ as directed by the Labour Court.

While this case was on-going, amendments to Employment Permits legislation were introduced. Section 4 of the Employment Permits (Amendment) Act 2014, which amends Section 2 of the Employment Permits Act 2003, allows a foreign national who, in contravention of the 2003 Act had entered employment without an Employment Permit, to take (or for the Minister to take on their behalf) a case for an amount of money to recompense the foreign national for such work done or services rendered, if they have taken all steps as were reasonably open to them to comply with the Act (Joyce and Whelan, 2015). 
The Employment Permits (Amendment) Act 2014 provided for undocumented migrants to take such a case against their former employer but their entitlement to back payments of wages would be limited to what they would be owed under the National Minimum Wage (as set in National Minimum Wage Act 2000).

As mentioned in Section 3 the Employment Permits (Amendment) Act 2014 also provides for a defence to a charge of having been employed without an Employment Permit, where it can be proved that the foreign national took all reasonable steps to ensure compliance with the section. It is possible for a legally resident non-EU national found to be illegally working to apply to change their status under Section 4(7) of the Immigration Act 2004 to a type of permission which permits access to the labour market. They must meet all the requirements of the immigration permission(s) which enable access to the Irish labour market such as obtaining an Employment Permit. This pathway is only open to those who have subsisting valid immigration permission to reside in the State.

According to the EMN Synthesis report on this Study, the most common outcome for illegally employed and irregularly staying non-EU nationals is the issuance of a returns decision. Illegally employed and regularly staying non-EU nationals may in some cases be recognised as victims of human trafficking or regularised in a small number of Member States (Belgium, Greece, Ireland, The Netherlands and Sweden) (European Migration Network, 2017). 


\section{SECTION 6}

\section{Conclusions}

Illegal employment can be considered a key pull factor encouraging irregular migration (European Commission, 2007). While economic policy is largely a Member State competence, illegal employment is a policy concern of the EU as it impacts upon migration policy. The extent of illegal work in Europe and Ireland is not easy to quantify due to limited data, owing in part to the clandestine nature of the problem. Due also to the fact that it is hidden, illegal employment often impacts upon workers' fundamental rights. Illegal work therefore intersects with migration policy, social policy and fundamental rights.

Ireland's illegal employment policy and legislation differs from that in place across the EU. Illegal employment at the EU level is governed by Council Directive 2009/52/EC on sanctions and measures against employers of illegally staying third-country nationals in all Member States except Denmark, Ireland and the United Kingdom. In Ireland illegal employment is governed by the Employment Permits Act 2003 and Employment Permits Act 2006, as amended by the Employment Permits (Amendment) Act 2014. Ireland's legal migration regime is not significantly influenced by EU policy, including policy on undeclared work.

This is the first comprehensive study on illegal employment concerning both regularly and irregularly staying non-EU nationals in Ireland, which outlines in detail policy and practice with input from a variety of stakeholders. Data on the size of the irregularly resident population or the extent of illegal employment of non-EU nationals in Ireland are not currently available from an official or objective source. Migrant Rights Centre Ireland (2014b) estimated in 2014 that there were between 20,000 and 26,000 undocumented migrant adults living and working in Ireland. In $2016 \mathrm{MRCl}$ recorded 511 undocumented migrants who provided information as to their initial status in the State; all entered the country legally, 55 per cent entered the country on a tourist visa and 35 per cent as a student.

The study shows that areas at high risk of illegal employment include the catering sector such as takeaway, fast food and ethnic restaurants; workers in the private home such as childcare workers, including those known as au pairs, and elderly carers. $\mathrm{MRCl}$ observed that the two most common types of illegal employment are students working outside the permitted hours and undocumented migrants. 
The student immigration system underwent a number of changes from 2011 designed to prevent student migration motivated by economic rather than educational reasons, including the introduction of limits on the number of times a student may register in Ireland for the purposes of study. In addition renewals became linked to academic progression. The student work concession which allows non-EU students to work 20 hours per week during term time and up to 40 hours per week during holidays without needing to hold an Employment Permit, has also been tightened. $\mathrm{MRCl}$ expressed the view that the significant section of the current population of irregular migrants in Ireland fell into following the move from a less regulated international student regime to one that is much more developed.

Despite the introduction of measures to enable students to maintain legal residence, for example the two-year Student Probationary Extension, research shows that the tighter requirements did lead to individuals falling into irregularity. Work outside of the concession hours is also still a common feature of student immigration in Ireland.

The study shows that the WRC does not routinely pass information regarding non-EU nationals who have permission to reside but who are breaching the conditions of their Employment Permit/residence permit to GNIB, but focuses on resolving the employment law breach. This position appears to be in line with the ILO principle that the function of the labour inspectorate is to enforce labour standards and identify breaches of employment law; further duties such as checking immigration compliance, should not interfere with or deter from this focus. The ILO has noted the challenge faced by labour inspectors in regard to irregular migrants, balancing the duty to report back any illicit facts against their role of protecting these workers' rights. The study finds that in the context of the illegal employment of non-EU nationals, it is more likely that a prosecution would occur under the Employment Permits Acts than under the Immigration Act 1999, as amended. Although the WRC has the power to prosecute both employers and employees, they will usually focus solely on the employer. $\mathrm{MRCl}$ observed that where a compliance issue is identified, employers are given the opportunity to rectify issues and this can result in undocumented workers losing their jobs.

The research highlights that non-EU nationals who engage in illegal work, in particular those who are undocumented, are often vulnerable to abuse of employment rights as well as fundamental or human rights. Research in the area suggests that irregularity impacts upon other aspects of life other than work, including family life, health services and education (Migrant Rights Centre Ireland, 2007; Migrant Rights Centre Ireland, 2014b; Platform for International Cooperation on Undocumented Migrants, 2010). Migrant Rights Centre Ireland (2015) suggests reforms to the Employment Permits system such as occupation- 
specific permits rather than employer specific permits; introducing transitional measures for persons between statuses, including Employment Permits; and implementing a regularisation scheme for undocumented migrants (see also Platform for International Cooperation on Undocumented Migrants, 2010). 


\section{REFERENCES}

Arnold, S. and E. Quinn (2017). Family Reunification of Non-EU Nationals in Ireland. Dublin: European Migration Network. Economic and Social Research Institute.

Clandestino Project (2009). 'Undocumented Migration: Counting the Uncountable. Data and Trends across Europe', Clandestino Project Final Report, European Commission.

Council of the European Union (2003). Council resolution on transforming undeclared work into regular Employment. (2003/C 260/01).

Cronin, M. (2013). 'The role of the Irish National Labour Inspection System (National Employment Rights Authority - NERA) as part of a strategic policy response to undeclared work'. ILO/EC Comparative Study on Labour Inspection Strategies for Combating Undeclared Work in Europe.

Department of Education and Skills (2010). Investing in Global Relationships: Ireland's International Education Strategy 2010-2015. Report of the High-Level Group on International Education to the Tánaiste and Minister for Education and Skills. Dublin: Department of Education and Skills. Available at: www.education.ie.

Department of Education and Skills (2015). Reform of the International Education Sector and Student Immigration System Government Policy Statement. Dublin: Department of Education and Skills. Available at: www.education.ie.

Department of Education and Skills (2016). Irish Education Globally Connected: An International Education Strategy for Ireland, 2016-2020. Dublin: Education in Ireland. Available at: www.education.ie.

Department of Education and Skills and Department of Justice and Equality (2014). Regulatory Reform of the International Education Sector and the Student Immigration Regime Policy Statement September. Dublin: Department of Education and Skills, www.education.ie. Available at: www.education.ie.

Department of Justice and Equality (2010). New Immigration Regime for Full-Time, nonEEA Students: Final Report and Recommendations of the Interdepartmental Committee. Dublin: Department of Justice and Equality.

Department of Justice and Equality (2015). Trafficking in Human Beings in Ireland. Dublin: Department of Justice and Equality.

Department of Justice and Equality (May 2015). Reform of the International Education Sector and Student Immigration System Government Policy Statement May 2015. Dublin: Department of Justice and Equality. Available at: www.inis.gov.ie.

Education in Ireland (2016). Why Study in Ireland? Dublin: Education in Ireland. Available at www.educationinireland.com.

Eurofound (2012). Ethnic entrepreneurship: Case study: Dublin, Ireland. Dublin: Cities for Local Integration Policy. Available at www.eurofound.europa.eu.

European Commission (2007). Communication from the Commission to the Council, the European Parliament, the European Economic and Social Committee and the Committee of the Regions - Stepping up the fight against undeclared work. $\mathrm{COM} / 2007 / 0628$ final. 
European Commission (2007). GREEN PAPER: Modernising labour law to meet the challenges of the 21st Century. COM (2006) 708 final.

European Migration Network (2014). Asylum and Migration Glossary 3.0. Brussels: European Migration Network.

European Migration Network (2017). Illegal employment of third-country nationals in the European Union. Brussels: European Migration Network.

European Union Agency for Fundamental Rights (2015). Severe labour exploitation: workers moving within or into the European Union: States' obligations and victims' rights. Luxembourg: Publications Office of the European Union.

Finn, M. and P.J. O'Connell (2012). Immigration of International Students to the EU: Ireland. Dublin: European Migration Network. Economic and Social Research Institute.

Gilmartin, M., P. Rojas Coppari and D. Phelan (2016). International Student Migration to Ireland. NIRSA Working Paper Series No. 80. Available at www.maynoothuniversity.ie.

Gusciute, E., E. Quinn and A. Barrett (2015). Determining Labour and Skills Shortages and the Need for Labour Migration in Ireland. Dublin: European Migration Network. Economic and Social Research Institute.

International Centre for Migration Policy Development. Clandestino Project Undocumented Migration: Counting the Uncountable Data and Trends Across Europe. Available at www.icmpd.org.

International Labour Organization (2013). Labour inspection and undeclared work in the EU. Geneva: International Labour Organization.

Irish Nationalisation and Immigration Service and Department of Education and Skills. (updated) (2016). Interim List of Eligible Programmes for Student Immigration Permission. Dublin: Irish Nationalisation and Immigration Service and Department of Education and Skills.

Irish Naturalisation and Immigration Service (2008). Administrative Immigration Arrangements for the Protection of Victims of Human Trafficking. Available at www.inis.gov.ie.

The Irish Times (17 March 2016). 'Overseas students: an international solution to an Irish problem?'. Available at www.irishtimes.com.

Joyce, C. (2014). Annual Policy Report on Migration and Asylum 2012: Ireland. Dublin: European Migration Network. Economic and Social Research Institute.

Joyce, C. and S. Whelan (2015). Annual Policy Report on Migration and Asylum 2014: Ireland. Dublin: European Migration Network. Economic and Social Research Institute.

Kingston, G., F. McGinnity and P.J. O'Connell (2015). 'Discrimination in the Labour Market: Nationality, Ethnicity and the Recession'. Work, Employment and Society. Vol. 29, Issue 2, pp. 213 - 232.

Migrant Rights Centre Ireland (2007). Life in the Shadows An Exploration of Irregular Migration in Ireland. Dublin: Migrant Rights Centre Ireland, www.mrci.ie. 
Migrant Rights Centre Ireland (2014a). Exploitation of Au Pair Workers in Ireland: Briefing Paper and $\mathrm{MRCl}$ Recommendations. Dublin: Migrant Rights Centre Ireland. Available at www.mrci.ie.

Migrant Rights Centre Ireland (2014b). Ireland is Home: An analysis of the current situation of undocumented migrants in Ireland. Dublin: Migrant Rights Centre Ireland. Available at www.mrci.ie.

Migrant Rights Centre Ireland (2015). All Work and Low Pay: The Experiences of Migrants Working in Ireland. Dublin: Migrant Rights Centre Ireland. Available at www.mrci.ie.

Migrant Rights Centre Ireland (2015a). Childcare in the Domestic Work Sector: Who's Minding the Children? Dublin: Migrant Rights Centre Ireland. Available at www.mrci.ie.

Migrant Rights Centre Ireland (2015b). Migrant Workers in the Home Care Sector: Preparing for the Elder Boom in Ireland. Dublin: Migrant Rights Centre Ireland. Available at www.mrci.ie.

Migrant Rights Centre Ireland (2015d). Workers On The Move: Past Lessons and Future Perspectives on Ireland's Labour Migration. Dublin: Migrant Rights Centre Ireland. Available at www.mrci.ie.

Migrant Rights Centre Ireland (2016). 'Ireland is Home 2016: A survey of 1008 undocumented migrants '. Dublin: Migrant Rights Centre Ireland. Available at www.mrci.ie.

National Employment Rights Authority (2012). Review of 2011. Carlow: National Employment Rights Authority. Available at www.workplacerelations.ie.

National Employment Rights Authority (2013). Review of 2012. Carlow: Department of Jobs, Enterprise and Innovation. Available at www.workplacerelations.ie.

National Employment Rights Authority (2014a). Review of 2013. Carlow: National Employment Rights Authority. Available at www.workplacerelations.ie.

National Employment Rights Authority (2014b). Guide to Employment Rights. Carlow: Department of Jobs, Enterprise and Innovation. Available at www.workplacerelations.ie.

National Employment Rights Authority (2015). Review of 2014. Carlow: National Employment Rights Authority. Available at www.workplacerelations.ie.

National Employment Rights Authority (2016). Review of 1st January to 30th September 2015. Carlow: National Employment Rights Authority. Available at www.workplacerelations.ie.

National Employment Rights Authority (n.d.). Who Can Work? Carlow: Department of Jobs, Enterprise and Innovation. Available at www.workplacerelations.ie.

Pan (2011). 'Student visas, undocumented labour, and the boundaries of legality: Chinese migration and English as a foreign language education in the Republic of Ireland'. Social Anthropology 19:3 pp.268-287.

Platform for International Cooperation on Undocumented Migrants (2016). Undocumented Migrant Workers: Guidelines for developing an effective 
complaints mechanism in cases of labour exploitation or abuse. Brussels: Platform for International Cooperation on Undocumented Migrants.

Platform for International Cooperation on Undocumented Migrants (2014). 'Words matter' - PICUM's campaign for accurate terminology when referring to undocumented migrants. Available at: http://picum.org/en/ourwork/terminology-words-matter-campaign.

Platform for International Cooperation on Undocumented Migrants (2010). PICUM's Main Concerns about the Fundamental Rights of Undocumented Migrants in Europe. Brussels: Platform for International Cooperation on Undocumented Migrants. Available at: http://picum.org/picum.org/uploads/publication.

Platform for International Cooperation on Undocumented Migrants (2015). Employers' Sanctions: Impacts on undocumented migrant workers' rights in four EU countries. Brussels: Platform for International Cooperation on Undocumented Migrants. Available at: http://picum.org/picum.org/uploads/publication/EmployerSanctions_Final.pdf.

Quinn, E. and E. Gusciute (2015). Strategies Used to Support Return Policy in Ireland. Dublin: European Migration Network. Economic and Social Research Institute.

Quinn, E. and G. Kingston (2012). Practical Measures for Reducing Irregular Migration: Ireland. Dublin: European Migration Network. Economic and Social Research Institute.

Raghuram, P. (2013). 'Theorising the Spaces of Student Migration'. Population, Space and Place 19:2. pp.138-154

Ruhs, M. (2005). Managing the Immigration and Employment of Non-EU nationals in Ireland. Studies in Public Policy 19. Dublin: The Policy Institute/Trinity College Dublin.

Share, M. and L. Kerrins (2009). The Role of Grandparents in Childcare in Ireland: Towards a Research Agenda. Irish Journal of Applied Social Care in Ireland 9:1. pp.33-47.

Sheridan, A. and S. Whelan (2016). Annual Policy Report on Migration and Asylum 2015: Ireland. Dublin: European Migration Network. Economic and Social Research Institute.

Smith, A. (2015). 'Part of the Family? Experiences of Au Pairs in Ireland' in Cox (ed.) Au Pairs' Lives in Global Context: Sisters or Servants? Basingstoke, Hampshire: Palgrave Macmillan, pp.170-186.

SOLAS (2015). National Skills Bulletin 2015. Dublin: SOLAS. Available at www.skillsireland.ie.

UNHCR (2013). A New Beginning: Refugee Integration in Europe. Brussels: UNHCR. Available at www.unhcr.org/protection/operations/52403d389/new-beginningrefugee-integration-europe.html.

Wall, K. and J. Sao Jose (2004). 'Managing Work and Care: A Difficult Challenge for Immigrant Families'. Social Policy \& Administration 38:6. pp.591-621. 
Workplace Relations Commission (2015). Inspection Services Case Management Procedures Manual. Carlow: Department of Jobs, Enterprise and Innovation. Available at www.workplacerelations.ie.

Workplace Relations Commission (n.d.). Guide to the Workplace Relations Commission. Carlow: Department of Jobs, Enterprise and Innovation. Available at www.workplacerelations.ie. 
EMN Ireland,

Economic and Social

Research Institute,

Whitaker Square,

Sir John Rogerson's Quay,

Dublin 2, Ireland

Telephone +353 18632000

Email emn.ireland@esri.ie

Web www.emn.ie / www.esri.ie

Twitter @ESRIDublin 